\title{
Artificial reefs and marine protected areas: A study in willingness to pay to access Folkestone Marine Reserve, Barbados, West Indies
}

Anne E Smith, Philip M Wheeler, Magnus L Johnson

Artificial reefs in marine protected areas provide additional habitat for biodiversity viewing, and therefore may offer an innovative management solution for managing for coral reef recovery and resilience. Marine park user fees can generate revenue to help manage and maintain natural and artificial reefs. Using a stated preference survey, this study investigates the present consumer surplus associated with visitor use of a marine protected area in Barbados. Two hypothetical markets were presented to differentiate between respondents use values of either: (a) natural reefs within the marine reserve or (b) artificial reef habitat for recreational enhancement. Information was also collected on visitors' perceptions of artificial reefs, reef material preferences and reef conservation awareness. From a sample of 250 visitors on snorkel trips, we estimate a mean willingness to pay of US\$18.33 (median - US\$15) for natural reef use and a mean value of US\$17.58 (median - US\$12.50) for artificial reef use. The number of marine species viewed, age of respondent, familiarity with the Folkestone Marine Reserve and level of environmental concern were statistically significant in influencing willingness to pay. Regression analyses indicate visitors are willing to pay a significant amount to view marine life, especially turtles. Our results suggest that user fees could provide a considerable source of income to aid reef conservation in Barbados. In addition, the substantial use value reported for artificial reefs indicates a reef substitution policy may be supported by visitors to the Folkestone Marine Reserve. We discuss our findings and highlight directions for future research that include the need to collect data to establish visitors' non-use values to fund reef management. 
1 Title: Artificial Reefs in Marine Protected Areas: A Study in Willingness to Pay for Folkestone Marine

2 Reserve, Barbados, West Indies

3

4 Authors names and affiliations:

5

6 *Anne Kirkbride-Smith,

7 Centre for Environmental and Marine Sciences, University of Hull, Scarborough, North Yorkshire,

8 YO11 3AZ, UK

9 A.Kirkbride-Smith@hull.ac.uk

10

11 Philip Wheeler,

12 Department of Environment, Earth and Ecosystems, The Open University, Milton Keynes, MK7 6AA,

13 UK

14 philip.wheeler@open.ac.uk

15

16 Magnus Johnson,

17 Centre for Environmental and Marine Sciences, University of Hull, Scarborough, North Yorkshire,

18 YO11 3AZ, UK

19 m.johnson@hull.ac.uk

20

$21 *$ Corresponding author:

22

23 E-mail address: A.Kirkbride-Smith@hull.ac.uk

24 Telephone number: 01723-357255

25

26

27

28

29 
34 Abstract

Artificial reefs in marine protected areas provide additional habitat for biodiversity viewing, and therefore may offer an innovative management solution for managing for coral reef recovery and resilience. Marine park user fees can generate revenue to help manage and maintain natural and artificial reefs. Using a stated preference survey, this study investigates the present consumer surplus associated with visitor use of a marine protected area in Barbados. Two hypothetical markets were presented to differentiate between respondents use values of either: (a) natural reefs within the marine reserve or (b) artificial reef habitat for recreational enhancement. Information was also collected on visitors' perceptions of artificial reefs, reef material preferences and reef conservation awareness. From a sample of 250 visitors on snorkel trips, we estimate a mean willingness to pay of US\$18.33 (median - US\$15) for natural reef use and a mean value of US\$17.58 (median - US\$12.50) for artificial reef use. The number of marine species viewed, age of respondent, familiarity with the Folkestone Marine Reserve and level of environmental concern were statistically significant in influencing willingness to pay. Regression analyses indicate visitors are willing to pay a significant amount to view marine life, especially turtles. Our results suggest that user fees could provide a considerable source of income to aid reef conservation in Barbados. In addition, the substantial use value reported for artificial reefs indicates a reef substitution policy may be supported by visitors to the Folkestone Marine Reserve. We discuss our findings and highlight directions for future research that include the need to collect data to establish visitors' non-use values to fund reef management.

\section{Introduction}

56

Coral reefs are of significant economic value to the scuba diving and snorkelling industries (Brander, van Beukering \& Cesar, 2007) and via these water-based activities, reef tourism contributes millions of dollars annually to coastal regions (Dixon, Scura \& van't Hof, 1993; Cesar \& van Beukering, 2004;

60 Sarkis et al., 2013). A majority of reefs are located along the coastal strips of developing countries

61 where people depend heavily on reef ecosystems for their livelihoods (Cesar, 2000; Cesar, Burke \& 
62 Pet-Soede, 2003; Burke et al., 2011). In St. Lucia and Tobago alone, direct spending by reef tourists in 632006 contributed an estimated US\$91.6 and US\$43.5 million to each economy, respectively (Burke et

64

65

66

67

68

69 70

al., 2008). More recently, Burke et al. (2011) reported values for global reef tourism at US\$50/ha/yr to US\$1,000/ha/yr. In Bermuda, Sarkis et al. (2013) calculated the average total economic value of their coral reefs at US\$722 million per year, from which US\$406 million was related to coral reef tourism. Despite the value of coral reefs to coastal populations for marine recreation, shoreline protection and fisheries production, among others (Moberg \& Folke, 1999), global reef decline continues as a result of various anthropogenic activities (Halpern et al., 2008; Smith et al., 2016).

Marine protected areas (MPAs) have become an effective means of conserving reef ecosystems from human impacts (Halpern, 2003; Lester et al., 2009), while still allowing for recreational use of resources including scuba diving and snorkelling (Thurstan et al., 2012). Considered by some to be the 'pinnacle' in marine conservation (Thurstan et al., 2012), an MPA is defined as "an area of sea especially dedicated to the protection and maintenance of biological diversity and of natural and associated cultural resources, and managed through legal or other effective means" (Department of the Environment, 2013). The last four decades have witnessed a proliferation of MPAs globally (World Data Base on Protected Areas (WDPA), 2013). Burke et al. (2011) note that over two and a half thousand marine parks and equivalent protected areas have been designated to conserve coral reef habitats, amounting to $6 \%$ of the worlds coral reefs being managed. The many conservation benefits of MPAs are well documented (e.g. Selig \& Bruno, 2010; Johnson \& Sandell, 2014; Leenhardt et al., 2015), including an increase in the size and biomass of fish species (Varkey, Ainsworthy \& Pitcher, 2012; Caselle et al., 2015; Sciberras et al., 2015). As a consequence, biological enhancement typically increases the attractiveness of marine parks to divers and snorkellers (Barker, 2003), though this in itself may cause a dilemma between protection and use of coral reef resources (Thurstan et al., 2012).

In general, MPAs manage visitor use of reefs through a system of zoning (Day, 2002; Roman, Dearden \& Rollins, 2007) and by implementing carrying capacity measures (e.g. Hawkins \& Roberts, 1997; Brylske \& Flumerfelt, 2004; Ríos-Jara et al., 2013). Increasingly however, marine managers are investigating other ways of reducing the impacts of underwater recreational activities. Artificial reefs in MPAs have been envisaged as a potentially interesting management solution to deal with visitation 
93 levels to natural reefs $(\mathrm{Oh}$, Ditton \& Stoll, 2008), by providing additional habitat for marine 94 biodiversity viewing (e.g. Wilhelmsson et al., 1998; van Treeck \& Schuhmacher, 1999; Polak \& 95 Shashar, 2012). This practice helps alleviate visitor pressures from sensitive or heavily used natural 96 reefs (Leeworthy, Maher \& Stone, 2006; Polak \& Shashar, 2012; Kirkbride-Smith, Wheeler \& 97 Johnson, 2013) and may contribute significant revenues to local host economies (e.g. Brock, 1994; 98 Wilhelmsson et al., 1998; Dowling \& Nichol, 2001; Johns et al., 2001; Johns, 2004; Pendleton, 2005; Oh, Ditton \& Stoll, 2008). However, the use of artificial reefs for amenity enhancement has not been without past criticism (Oh, Ditton \& Stoll, 2008). Such condemnation has largely been due to the ubiquitous use of 'materials of opportunity' for reef creation (Stone et al., 1991; Tallman, 2006), including car tyres (Collins, Jensen \& Albert, 1995; Collins et al., 2002). Nevertheless, well conceived artificial reefs may facilitate various management strategies within protected waters including influencing the location of recreational use (Leeworthy, Maher \& Stone, 2006; Polak \& Shashar,

Despite the potential efficacies of MPAs (Halpern \& Warner 2002; Halpern, 2003; Lester et al., 2009), many fail to meet management objectives (Burke, Selig \& Spalding, 2002; Burke \& Maidens, 2004; Wells, 2006; Burke et al., 2011; De Santo, 2013), are severely under funded (e.g. Alder, 1996; Depondt \& Green, 2006) and exist as 'paper parks' only (Brandon, Redford \& Sanderson, 1998; Bruner et al., 2001; Bonham, Sacayon \& Tzi, 2008; Mora \& Sale, 2011). Various funding mechanisms exist for MPAs including personal donations, lottery revenues, international assistance and government taxes (Spergel \& Moye, 2004). However, none of these mechanisms are wholly reliable.

114 For instance, government taxes can be re-directed to responsibilities elsewhere (Lindberg, 2001),

115 especially in times of economic difficulties (Spergel \& Moye, 2004). Reef-based tourism is considered 116 to be a lucrative means of financing protection of marine parks (e.g. Dharmaratne, Sang \& Walling, 117 2000; Depondt \& Green, 2006; Peters \& Hawkins, 2009), through the recovery of user fees from 118 visitors. Techniques, including the contingent valuation method of willingness to pay (WTP), can be 119 used to determine the level visitors would contribute. ${ }^{1,2}$ Fees collected, can increase the management 120 capacity of parks through for example; education, scientific monitoring and enforcement (Hime, 2008;

\footnotetext{
${ }^{1}$ Contingent valuation is a survey-based methodology for eliciting values people place on goods, services and amenities (Boyle, 2003).

${ }^{2}$ WTP is defined as, "the maximum amount a person is willing to pay for a good or service" (Waite et al., 2014).
} 
121 Uyarra, Gill \& Côté, 2010), collectively helping sustain future conservation of reefs. However, many 122 marine reserves remain free to use, or charge a nominal entrance fee (Peters \& Hawkins, 2009; Terk \& 123 Knowlton, 2010), despite evidence that in some circumstances, user fees could increase substantially 124 with little impact on visitor numbers (Thur, 2010).

Bryant et al. (1998) and Burke et al. (2011) emphasize the need for countries harbouring coral reefs to conduct applied valuation techniques to help underpin decision and policy-making. An integral part of WTP studies is to discern what motivates people to donate funds. The non-economic motives behind WTP for biodiversity conservation have been explored (Martín-López, Montes \& Benayas, 2007) with results proposing familiarity and biophilia as having a marked effect on payment attitudes. Some authors (e.g. Cooper, Poe \& Bateman, 2004; Spash, 2006) suggest that intrinsic value is the main motivator explaining visitor's choice to contribute, as is bequest value that benefits future generations

133 (Hargreaves-Allen, 2010). Researchers have also sought to establish what factors influence how much visitors are prepared to pay. Studies indicate that users of reefs (usually divers and snorkellers surveyed) are willing to allocate more money for an increase in the abundance or quality of a specific reef attribute or group of attributes (e.g. Rudd \& Tupper, 2002; Schuhmann, Casey \& Oxenford, 2008; Polak \& Shashar, 2013). Additionally, the opportunity of viewing charismatic mega-fauna, including marine turtles and whale sharks, is greatly valued (Hargreaves-Allen, 2010; Schuhmann et al., 2013; Farr, Stoeckl \& Beg, 2014). Conversely, studies have noted losses in consumer surplus relating to the demise of coral reefs. ${ }^{3}$ For example, Doshi et al. (2012) reported a reduction in divers' welfare identified by their decrease in WTP for bleached coral reefs.

143 Numerous researchers (e.g. Dixon, Scura \& van't Hof, 2000; Arin \& Kramer, 2002; Barker, 2003;

144 Mathieu, Langford \& Kenyon, 2003) have undertaken contingent valuation surveys to measure 145 visitors' WTP for marine park entry (Table 1). In a meta-analysis detailing 18 studies, Peters \& 146 Hawkins (2009) found an overwhelming approval of users to pay marine park access fees, or an 147 increase in fees, where charges currently existed. Additionally, there is evidence that user fees can 148 generate sufficient funds to cover a significant share of MPA operating costs (Spergel \& Moye, 2004).

149 For example, in Australia’s Great Barrier Reef Marine Park, tourist-based user fees of US\$5 million

\footnotetext{
${ }^{3}$ Consumer surplus is the difference between the price that consumers pay and the price that consumers are willing to pay (Bateman et al., 2002).
} 
150 contributed around $20 \%$ of the budget of the park authority in 2002/2003 (Skeat \& Skeat, 2003). On

151 Bonaire, user fee collections of around US\$1 million represented 93\% of the income required to 152 operate the National Marine Park in 2008 (STINAPA, 2009; Uyarra, Gill \& Côté, 2010).

153

154 To date, there has been a clear emphasis on measuring the consumer surplus of visitors' recreational 155 use of natural reefs (reviewed in Peters \& Hawkins, 2009). In contrast, only a handful of contingent

156 valuation studies appear to have measured visitors' consumer surplus relating to recreation-orientated 157 artificial reefs (Bell, Bonn \& Leeworthy, 1998; Ditton \& Baker, 1999; Johns et al., 2001; Johns, 2004;

158 Crabbe \& McClanahan, 2006; Oh, Ditton \& Stoll, 2008; Hannak et al., 2011; Chen et al., 2013).

159 However, none of these studies used marine park user fees as the payment vehicle to estimate 160 consumer surplus, and just three papers (Johns et al., 2001; Johns, 2004; Oh, Ditton \& Stoll, 2008)

161 estimated recreational values of artificial and natural reefs in the same locality. To address this dearth

162 of information, a valuation study was developed that encompassed both artificial and natural reef

163 habitats within a MPA.

164

The main purpose of this analysis was to investigate the present consumer surplus associated with visitor use of a MPA in Barbados, using the contingent valuation method. We discuss our findings with relevance to visitors funding reef conservation and highlight the potential that reserves and artificial reefs have for symbiotic partnerships in coral reef management.

2. Methods

\subsection{Study Setting}

174 This study was conducted on the west (leeward) coast of Barbados $\left(13^{\circ} 10^{\prime} \mathrm{N}, 59^{\circ} 32^{\prime} \mathrm{W}\right)$ between the months of July to August 2013, over an 18 day period. Akin to many Caribbean islands, the tourism appeal of Barbados depends on its coastal environment. Coral reefs fringing the southwest coast (Lewis, 1960) provide a diversity of recreational opportunities including scuba diving, snorkelling and sub-marine viewing. Schuhmann, Casey \& Oxenford (2008) estimate that between 30,000 and 50,000 divers visit the island per year and the Inter-American Biodiversity Information Network (2010) report a further 176,600 visitors participating in snorkel trips. As a way of 
181 diversifying the marine tourism industry, several artificial reefs have been deployed along the

182 south-west coast (Agace, 2005).

183

184 One small MPA $\left(2.1 \mathrm{~km}^{2}\right)$ the Folkestone Marine Reserve, is located in the parish of St. James on

185 the western side of the island (Cumberbatch, 2001). The reserve extends for $2.2 \mathrm{~km}$ along the

186 coastal fringe and stretches outwards between 660-950 m offshore (Fig. 1). Legislated in 1981

187 (Cumberbatch, 2001), the marine reserve protects $0.32 \mathrm{~km}^{2}$ of accessible fringing, patch and bank

188 reef (Inter-American Biodiversity Information Network, 2010) and nesting sites of the endangered

189 hawksbill turtle Eretmochelys imbricata (Horrocks \& Scott, 1991; Beggs, Horrocks \& Krueger,

190 2007). A small artificial reef consisting of a disused barge (approximately $8 \mathrm{~m}$ long), that provides

191 a site for instructor-led dives and for snorkellers, is situated within the reserve (Fig. 1).

192 Encompassing just 11\% of the coastline (Cumberbatch, 2001), the reserve attracts multiple

193 stakeholders and represents the most heavily used recreational space in Barbados (Blackman \&

194 Goodridge, 2009), including approximately 7,000 scuba divers using the Folkestone reefs per year

195 (Inter-American Biodiversity Information Network, 2010). In anticipation of potential user conflict,

196 the reserve has been divided into four distinct zones (Cumberbatch, 2001) (Fig. 1). The sites used

197 for this study were located within the Folkestone Marine Reserves Zone D - southern water sports

198 zone (principally Sandy Lane patch reef and the disused barge - Site 1) and a site to the outside of

199 the northern reserve boundary (Site 2), adjacent to the Lone Star reef (Fig. 1).

200

2012.2 Valuation Method and Related Issues

202

203 In order to estimate maximum WTP, the surveys (Supplementary Material) adopted a payment card

204 contingent valuation method. Other common response formats used to measure demands for non-

205 market goods, are single- and double-bounded dichotomous choice and open-ended questioning

206 techniques. All four valuation approaches are subject to some degree of bias (Bateman et al., 2002;

207 Boyle, 2003), though this can be reduced with the careful design and pre-testing of surveys (e.g. Boyle

208 et al., 1998). Despite various biases, each of these stated preference techniques uses hypothetical

209 market scenarios to discern a respondent's likely behaviour under various conditions of either WTP, or

210 willingness to accept, for an increase/decrease in a public good. In the case of the payment card

211 approach, it uses an ordered set of threshold values that respondents are asked to peruse and indicate 
212 the highest amount they are willing to pay. Bateman et al. (2002) and Boyle (2003) outline the various

213 advantages of payment cards including the avoidance of anchoring and 'yea saying' to a sole bid

214 presented (a problem in dichotomous choice) and the avoidance of starting point bias. In addition,

215 Mitchell \& Carson (1989) suggest payment cards can assist in reducing non-response rates and

216 eliminate the need for prompting by the interviewer. They have also been shown to yield WTP

217 estimates that are more conservative than those generated using other stated preference techniques

218 (Champ \& Bishop, 2006; Thur, 2010). Payment cards are however, subject to specific forms of bias

219 relating to the design configuration in range of monetary values and size of intervals chosen (Bateman

220 et al., 2002). In fact, in payment card data, the true WTP value is thought to lie between the bid

221 amount chosen and the next highest value up on the payment card (Cameron \& Huppert, 1989;

222 Bateman et al., 2002; Boyle, 2003). Thus intervals rather than 'point' valuations are used in most

223 statistical models.

224

225

\subsection{Survey Design and Data Collection}

226

227

An initial site visit to the Folkestone Marine Reserve was conducted in 2012, to determine if any

228 entrance fee payment was already in place (of which there were none) and to determine visitor trips/user patterns within the reserve. Additionally, an informal focus group consisting of snorkellers and divers was held to ascertain the range of bid values to be used in the data collection instrument. Two versions of the survey were produced; one aimed at valuing artificial reefs and the second aimed at valuing natural reefs. Both instruments were identical with the exceptions of sentence three and the word 'artificial reef' in sentence five of the artificial reef valuation question (presented below), which were omitted from the natural reef script. The payment vehicle used was a daily, per person user fee into the marine reserve. The final survey consisted of 46 questions divided into five sections. A majority of the questions were closed-ended, as Champ (2003) suggests this format helps avoid respondent fatigue and simplifies statistical analysis in WTP 238 studies.

The first section explored respondents demographic characteristics that included number of years spent in education, country of residence and age. In this section also, participants were asked questions relating to their length of stay in Barbados and about any previous visits to the island. In 
243 the second section, visitors were questioned about their marine recreation participation. A 5-point

244 Likert rating scale (range: very experienced to very poor) was presented to establish their

245 snorkelling proficiency. To gauge the experience of those participants that had scuba diving

246 ability, we asked for the number of dives they had logged in their diving history. A similar scale

247 (range: very satisfied to very dissatisfied) was also used to assess visitor satisfaction with

248 snorkelling, and if applicable, diving on the island. The final question in section two assessed

249 which marine related activities respondents had undertaken during their present stay. In the third

250 part of the survey, the hypothetical valuation scenario was presented to establish each visitor's

251 WTP bid amount. The valuation script (Supplementary Material) contained background

252 information pertinent to the reefs within the reserve and the challenges encountered in managing

253 them. A laminated map of the reserve (Fig. 1) was shown to each visitor prior to the WTP question

254 being asked, as were photos of common species found within the reserve. Additionally, in the

255 artificial reef survey, laminated cards of popular artificial reef materials were presented

256 (Supplementary Material). The exact wording of the valuation question presented in the artificial

257 reef survey was:

258

259

Today, no Folkestone Marine Reserve fee is paid by you to visit the coral reefs and marine species within this protected area. All funding to conserve the reefs here is sourced elsewhere. There is a proposal to develop one or more artificial reefs within the marine reserve for both snorkelling and diving (show map and explain). A visitor user fee (held in a trust fund) would be used to help manage and maintain the artificial reefs within the reserve. With this in mind, I am going to show you a set of numbers in US dollars. Please consider your total trip costs for this visit and tell me; what is the maximum you would be willing to pay 'over and above your present trip costs' as a daily user fee to recreate in the Folkestone Marine Reserve?

The survey presented 12 payment values in ascending order (Champ, 2003) from US\$0 to US\$60 (Table 2), from which respondents were asked to choose a value (or to specify another amount if above US\$60) as an indication of their WTP to help manage and maintain the reefs within the reserve. Section three of the survey also included follow-up questions exploring the rationale given

272 for a bid value, or if a zero bid was given, the reason for that particular choice. We also asked 
274 enquired about any concerns relating to the management of funds raised. The fourth section of the 275 survey was used to query respondents on their knowledge and use of artificial reefs, both in

276 Barbados and elsewhere in the world. We included a specific question to identify respondents

277 preferences, placed in rank order, relating to types of materials used for artificial reef creation. At

278 this point of enquiry, three laminated cards with images of artificial reefs were shown to

279 individuals (Supplementary Material). Three questions were also embedded in section four to help

280 capture each visitor's environmental awareness and general concern for reefs and the marine

281 environment. The final part of the survey aimed to establish respondent's prior and current

282 experience(s) of the Folkestone Marine Reserve. We asked visitors to use a 5-point Likert rating

283 scale (range: very good to very poor) to rate the quality of the seawater, coral and fish life

284 encountered on their present trip. A question was also used to establish what marine life visitors

285 had viewed whilst underwater. Finally, respondents were requested to score their overall

286 experience of the reserve on a 4-point Likert rating scale (range: exceeded expectations to not

287 satisfied expectations) after which visitors were asked to clarify if they had plans to return to the

288 reserve in future.

289

290 A preliminary test of the survey $(n=20)$ was conducted in Barbados on the target population and

291 changes made accordingly, prior the main data collection period. Dharmaratne \& Brathwaite

292 (1998) emphasize the importance of choosing respondents familiar with the good being valued,

293 thus the sample frame population consisted of snorkellers and/or divers with prior experience of

294 either activity. In addition, English speaking overseas tourists of any nationality, between the ages

295 of 18 to 70 years visiting the reserve, were a requirement. As very few Barbadian residents snorkel

296 or scuba dive (Inter-American Biodiversity Information Network, 2010), they were not included in

297 the surveying process.

298

299 Visitors to the Folkestone Marine Reserve were approached on board Tiami catamaran cruise trips

300 (www.tiamicruises.com). These 5 hour snorkel trips, at a cost of US\$85 per person, provide

301 visitors with two 30 minute snorkel stops (Fig. 1) and a beach visit. A sampling technique was

302 chosen to examine the population by approaching every other seated tourist, moving systematically

303 from the front to the rear of the catamaran. In view of the fact that interview context has been

304 reported as a significant determinant of WTP (Arrow et al., 1993; Hime, 2008; Hargreaves-Allen, 
305 2010) all interviews were conducted personally using the same location (i.e. on-board a Tiami

306 catamaran) and after experiencing the reserves underwater environment. Each interview took

307 approximately 20 minutes to complete. For consistency, the same two interviewers administered

308 both surveys on a rotational (daily) basis, initially giving each respondent a short introduction to

309 explain the reasons for the survey. Only one survey type was administered to each respondent.

310 Prior to the bid valuation question being presented, it was emphasized that no user fee is currently

311 imposed on visitors to the reserve. All visitors who participated in the survey gave their permission

312 to use the results on an anonymous basis.

313

314 2.4 Data Analysis and WTP Estimations

315

316 Responses were analyzed using SPSS (Version 19) and R (R Development Core Team, 2008). To

317 investigate differences between the responses given in survey 1 (artificial reef scenario) and survey

3182 (natural reef scenario), we applied Chi-square tests with Yate's Continuity Corrections for

319 categorical data, and Mann-Whitney U tests (two-tailed) for continuous data. Variations in WTP

320 were investigated for several variables (e.g. between snorkellers and divers and for Likert scale

321 questions) using Mann-Whitney U tests (two-tailed) and Kruskal-Wallis tests, where applicable.

322 Consistent with the method adopted in Fitzsimmons (2009), a distinction was made between the

323 experience level of participant divers, denoted by two categories; novice divers $(<100$ logged

324 dives) and experienced divers ( $\geq 100$ logged dives).

325

326 Data were screened for zero bids (US\$0), with each bid individually assessed via the follow up 327 questions, as to why the respondent was not prepared to pay. Mean and median WTP, prior to and

328 after zero bid removal, were compared. Following Bateman et al. (2002), zero bids were excluded 329 from the data prior to calculating mean and median WTP for all models. Significant differences

330 between the two study populations were tested to ensure that specific characteristics of the sample

331 (e.g. age and gender) had not been systematically biased. Standard errors and 95\% confidence

332 intervals of estimates of WTP were calculated using bootstrapping (Kling \& Sexton, 1990) based

333 on 1,000 replications.

334

$335 \quad 2.5$ Econometric Analysis 
337 The theoretical foundation of WTP is based on the assumption that individuals derive utility from consumption of an environmental public good and are assumed to maximize their utility given income and commodity prices. WTP is hypothesized to be influenced by a number of independent variables (Arin \& Kramer, 2002) represented by the vector $\boldsymbol{x}$.

$$
W \boldsymbol{P P}_{i}=\boldsymbol{\beta}^{\prime} \boldsymbol{x}_{i}+\varepsilon_{i}
$$

where $\boldsymbol{\beta}$ is a vector of slope parameters to be estimated and $\boldsymbol{x}_{\boldsymbol{i}}$ is a vector of observations on the explanatory variables for individual $\boldsymbol{i}$. The error term $\boldsymbol{\varepsilon}_{\boldsymbol{i}}$ is assumed to be normally distributed.

Payment card data were analyzed using interval regression (Bateman et al., 2002), as it is thought that the true payment value given lies between the value chosen and the value bounding the upper interval of that category (Cameron \& Huppert, 1989). Thus for the payment card sample, a maximum likelihood estimation (MLE) procedure was used (Cameron \& Huppert, 1989) that accommodates the intervals, that is the probability that WTP falls in the range defined by the lower limit $\boldsymbol{t}_{\boldsymbol{l}}$ and the upper limit $\boldsymbol{t}_{\boldsymbol{u}}$, represented by the adjacent payment card value given by;

353

354

355

356

357

$$
\begin{aligned}
\operatorname{Pr}\left(\log w_{i} \subseteq\right. & \left.\left(\log t_{l i}, \log t_{u i}\right)\right) \\
& \left.=\operatorname{Pr}\left(\log t_{l i}-X_{i}^{\prime} \beta\right) / \sigma<z_{i}<\operatorname{Pr}\left(\log t_{u i}-X_{i}^{\prime} \beta\right) / \sigma\right),
\end{aligned}
$$

where $z_{i}$ is the standard normal random variable. Arin \& Kramer (2002) note that because the probability given by the latter equation can be written as the difference between two standard cumulative densities a likelihood function can be defined over the parameters $\boldsymbol{\beta}$ and $\boldsymbol{\sigma}$. In the study, interval boundary parameters were estimated using the survival package (Therneau, 2014).

For comparison, an ordinary least squares regression model was also applied. In the latter model, the precise mid-point of each interval category is used as the dependent variable of WTP. Normality is assumed for the regression models (Cameron \& Huppert, 1989), with a lognormal conditional distribution proposed as a first approximation. Many researchers have adopted 
367 Cameron \& Hupperts (1989) method in WTP studies using payment cards (e.g. Arin \& Kramer, 368 2002; Blaine et al., 2005; Mahieu, Riera \& Giergiczny, 2012; Yang, Hu \& Liu, 2012), as one of the 369 advantages is that value estimates can be interpreted in a straightforward manner (as apposed to

$370 \log$ transformed data). Also, by using both interval regression and an ordinary least squares model, 371 it helps validate the payment card range presented and serves as an ad hoc check of the normality 372 assumption. The stepwise backward elimination method was employed for both regression models 373 to investigate the effects of 12 independent predictor variables (Table 3) on visitors' total WTP. 374 Variables that did not yield covariates significant at $\leq 10 \%$ level were excluded from the final 375 model.

376

377

\section{Results}

378

379

3.1 Visitor and Holiday Characteristics

380

381 Two hundred and fifty surveys were completed during the study period divided equally between

382 the two reef scenarios $(n=125$ for each survey). An almost equal sex ratio ( $51 \%$ female) was

383 recorded from both surveys combined. The majority of visitors resided in the United Kingdom

$384(72 \%)$, followed by the United States (12\%), with 5 additional countries (Canada, Brazil, Norway,

385 Italy and the Caribbean Island States) making up the sample. The mean and median age of

386 respondents was $38( \pm 13.6$ s.d.) and 40 years respectively, with an age range of $18-69$ years

387 recorded. The total number of years visitors had spent in education ranged from $11-27$ years with

388 the average length being $16( \pm 3.3$ s.d.) years. Over a third $(38 \%)$ of those surveyed, were repeat

389 visitors to Barbados with a mean of 3 ( \pm 3.9 s.d.) visits (including the present one). The number of

390 nights being spent on the island ranged from $2-30$ nights, with the majority (50\%) of respondents

391 having an average duration of 12 ( \pm 3.9 s.d.) stop-overs. Group differences investigated between

392 survey 1 and survey 2 identified one variable; Age being statistically different between the two

393 surveys $(U=6173, z=-2.206, p \leq 0.027, r=0.14)$. Artificial reef survey participants were slightly

394 older than natural reefs survey participants; means: $39( \pm 14.25$ s.d.) and $36( \pm 12.7$ s.d.) years,

395 medians: 43 and 36 years, respectively. Data from the Caribbean Tourism Organization (2014) for

396 visitors to Barbados in 2013 were used to assess for sample representativeness. From the limited 
397 data available, tourist stop-over arrivals for that year suggest that our sample was over-represented

398 by UK respondents. Additionally, no cruise ship tourists were available for interview.

399

400

3.2 Marine Recreation Participation

401

402 Prior to the survey being administered, visitors had carried out $3.75( \pm 0.9$ s.d.) activities whilst on 403 vacation. The majority had relaxed on the beach (85\%), swam (81\%), snorkelled from the shore 404 (39\%), kayaked (21\%) and scuba dived (12\%). The majority of snorkellers described themselves 405 as being average (50\%) to very good (31\%) at the sport, while $17 \%$ suggested they were poor and 406 a further $2 \%$ very poor at snorkelling. Respondents that had scuba diving ability $(n=76)$, had an 407 average of 32 ( \pm 86.81 s.d.) previously logged dives and a median of 10 dives [interquartile range: 408 2-25]. Seventy-four percent of the sample had been given a snorkelling and/or diving briefing at 409 some point in their life. When visitors were asked to rate their satisfaction with snorkelling on the 410 island in general, $83 \%$ was either satisfied (41\%) or very satisfied (42\%) with the experience, with 411 the remainder being ambivalent. Respondents who had dived $(n=39)$ whilst visiting Barbados, 412 were all either satisfied (66\%) or very satisfied (34\%) with their prior experiences.

413

414 3.3 The Folkestone Marine Reserve WTP

415

416 A total of 7 zero bids (Table 4) for WTP were identified. Follow-up questions were asked to 417 establish the reason why a zero bid was given. Four individuals were uncertain the money would 418 be spent on reef conservation per se, while the remaining respondents were unsure their 419 contributions would make any difference to the condition of the reefs in the Folkestone Marine 420 Reserve.

421

422 Zero bids were removed and mean and median values calculated for pooled data and for each 423 survey type (Table 4). Mean values were higher than median values for all estimates calculated. 424 This was due to positive right skews in the WTP distributions. The removal of the few zero bids 425 had a meager US\$0.51 impact on mean WTP (Table 4), which did not bias the results. For pooled 426 data, mean WTP (person/day) was estimated at US\$17.96 with a lower bound of US\$16.62 and an 427 upper bound of US\$19.27, at a 95\% confidence interval. Visitors who participated in the natural 
428 reef survey, had a higher mean WTP of US\$18.33, in comparison to mean values estimated for 429 visitors presented with the artificial reef survey; US\$17.58. The median value was also higher for 430 the natural reef scenario (US\$15) than for the artificial reef scenario (US\$12.50). Differences in 431 WTP between the two survey types were not significant $(U=7291, z=-.167, p \geq 0.867, r=.01)$. 432

433 Table 5 shows differences in mean WTP for selected variables. Females had a significantly higher 434 WTP of US\$19.54, compared with a value of US\$16.31 estimated for males. Visitors, who had 435 viewed a turtle while snorkeling, had a value of US\$19.59 compared with US\$11.56 for those who 436 had not viewed a turtle. This latter difference of US $\$ 8.03$ was highly significant. Divers, who had 437 experienced the underwater environment within the reserve prior to being interviewed, had a lower 438 WTP of US\$12.50, compared with divers visiting the reserve for the first time of US\$18.55.

439 Finally, repeat catamaran trip visitors had a significantly lower bid value of US\$13.37, compared 440 with individuals who were first time visitors to the reserve of US\$18.45. From a point of interest, 441 snorkellers and those who had diving ability had a very similar mean bid value of US\$17.89 and 442 US\$16.45, respectively.

443

444 Motivations of respondents' WTP were explored. Most visitors (75\%) reported that they would 445 pay a user fee to help preserve coral reefs for future generations, followed by $10 \%$ indicating it 446 gave them genuine pleasure to contribute towards reef conservation. A motivator of being a 'moral 447 duty' to contribute was also important among $8 \%$ of visitors. Of those who were willing to pay, $44870 \%$ reported concerns over the legitimate use of monies collected for reef conservation, while the 449 remaining $30 \%$ of visitors reported no concerns. Content analyses of the follow-up questions to understand these concerns revealed that most individuals were anxious that the funds raised would be spent elsewhere; typically on other government projects in Barbados. Respondents were also 452 asked which type of organization they would prefer to manage the user fee revenues. An environmental non-governmental organization was clearly the most popular choice yielding $75 \%$ support, followed by the government of Barbados (13\%) and public sector (3\%), while $9 \%$ chose a mix of all three authorities. The question that queried respondents in relation to where they would prefer to see park fee revenues spent, yielded a high level of support for marine education/children's outreach programmes (47\%) and for recreational artificial reefs (27\%).

458 Scientific monitoring also appeared important with $18 \%$ of respondents choosing this item. In 
459 contrast, land-based tourist facilities (1\%) and marine reserve patrols (2\%) seemed unimportant 460 investments.

461

4623.4 Perceptions and Use of Artificial Reefs and Environmental Concern

463

464 Artificial reef awareness was high amongst the population sampled with $69 \%$ having heard of the 465 term artificial reef, and 82 respondents (34\%) having either snorkelled or dived on an artificial reef 466 previously. When asked to rate their experience of this type of reef, $79 \%$ of snorkellers and $88 \%$ of 467 divers rated their prior experiences as good to very good. Additionally, 35 respondents had used 468 local artificial reefs, the majority $(n=29)$ situated in Carlisle Bay and the remaining 6 individuals 469 using the SS Stavronikita, the largest wreck to dive on in the Caribbean (Agace, 2005).

471 Three reef material types were presented using visual aids (Supplementary Material). The most 472 preferred material choice was a shipwreck (73\%), followed by Reef Balls ${ }^{\mathrm{TM}}$ (as a snorkel trail) 473 (17\%), with underwater art chosen by only 10\% (Fig. 2). Asked whether the creation of an 474 artificial reef in the Folkestone Marine Reserve would encourage a repeat visit, 77\% answered yes, $47512 \%$ no and $11 \%$ were unsure.

476

477 When questioning respondents if they were a member of an environmental group, only $10 \%$ 478 responded positively. In contrast, 83\% of visitors read or watched on television topics about 479 marine life and marine conservation. Respondents rated their level of concern relating to coral 480 reefs and the marine environment (on a scale of $1-10$, with 1 being the least concerned) with a 481 mean and median value of 7 ( \pm 1.77 s.d. $)$.

482

483 3.5 Experience of the Folkestone Marine Reserve 484

A fifth $(n=49)$ of respondents had previously visited the reserve on catamaran snorkelling cruises, 486 with $1.84( \pm 2.63$ s.d.) former trips recorded. All respondents said they had snorkelled during these trips. Additionally, 24 respondents that had previously dived in the reserve, had conducted $4.88( \pm$ 488 4.31 s.d.) dives there. 
490 Respondents were asked to recall the number of 'species' viewed. The marine life noted in the 491 study was; fish, coral, turtles, eels, manta rays and sea urchins. A majority of visitors recalled 3 492 species $(3.4( \pm 1.11$ s.d. $)$, median and mode $=3)$ with a maximum of 6 species seen, with no person 493 being noted as viewing no marine life. The most common species recalled were fish, spotted by $49495 \%$ of people, followed by a turtle noted by $80 \%$ of visitors.

495

496

Thirty-two percent of respondents had their expectations of the visit to the reefs exceeded and a

497

498

499

500

501

502

503

504

505

506

507

508

509

510

511

512

513

514 The results of the ordinary least squares and interval regression models are presented in Table 6.

515 Our results showed consistency in the coefficient estimations obtained between the two regression

516 models, suggesting the payment card design used for the surveys was well ordered (Cameron \&

517 Huppert, 1989) and/or the normality assumption was well maintained by the data (Yang, Hu \& Liu, 518 2012).

519

further 55\% were noted as being satisfied. Only 19 individuals said the trip had made no difference to them, while 8 visitors had not had their expectations satisfied. A significant relationship occurred between visitors' WTP and their level of satisfaction with the marine park (KruskalWallis test; $\left.x^{2}(3)=12.32, p \leq 0.006\right)$. Further post hoc analysis revealed the two groups most dissatisfied/ambivalent with the trip (when combined), had a significantly lower WTP than the two 'satisfied' groups combined $(U=961.500, z=-1.960, p \leq 0.050, r=0.16)$. When visitors were asked if they would return to the Folkestone Marine Reserve in the future, the majority (80\%) said they would, while the remainder said no.

Seawater (in terms of clarity) was rated highly by visitors, with a mean value of $4.48( \pm 0.43$ s.d.) recorded. Fish life was rated above average with a mean of $3.80( \pm 0.88$ s.d.). Coral life however, received the lowest mean rating of $3.26( \pm 0.99$ s.d.). It was found that snorkellers and divers differed in their ranking of coral life, with snorkellers rating this attribute significantly higher than divers $(U=5510, z=-2.196, p \leq 0.028, r=0.14)$.

\subsection{Econometric Analysis}

2012).


520 The explanatory powers of the ordinary least squares models were good, yielding $\mathrm{r}^{2}$ values of $39 \%$, 521 or above (Table 6). Overall, five of the twelve estimated coefficients expected to influence WTP, 522 were statistically significant. Based on previous research (Arin \& Kramer, 2002; Lindsey \&

523 Holmes, 2002; Seenprachawong, 2003; Togridou, Hovardas \& Pantis, 2006; Hargreaves-Allen,

524 2010), variables expected to show significant explanatory power, but in the event did not, included 525 number of years in education, previous catamaran trips and number of prior visits to Barbados. Of 526 the variables found to be significant, three (Age, Env_concern and Species_view) were significant

527 at the 1\% level (Env_concern 5\% significance level for the artificial reef survey), whilst

528 Dive_FMR was marginally significant at the $10 \%$ level. Two variables (Age and Dived_FMR) had 529 negative signs on the coefficients, implying that younger respondents and those who had not

530 previously dived in the reserve were prepared to pay more as a daily Folkestone Marine Reserve

531 fee. The coefficients for the remaining three variables (Env_concern, Coral_life and Species_view)

532 were positive. This indicates that respondents who rated the coral life as good, reported higher

533 levels of concern for the reefs and marine environment and viewed more marine life, had higher

534 WTP. It should be noted, the variable Coral_life was only significant in the natural reef model. 535

536 The regression results indicated the variable 'Species_view' made the largest unique contribution 537 to the variance in WTP, with a mean value of $22 \%$ noted across all data sets. A one unit increase 538 elevates WTP on average US\$5.69 - US\$5.81 for each additional species viewed (Table 6).

539

540 A Kruskal-Wallis Test indicated a high level of association between the dependent variable and

541 Species_view $\left(x^{2}(5)=133.39, p \leq 0.001\right)$ (Fig. 3). Further post hoc analysis confirmed significant

542 differences in WTP occurring between 'two and three' species viewed, 'three and four' species

543 viewed and 'four and five' species viewed $(U=1119, z=-3.391, p \leq 0.001, r=0.30 ; U=1154, z$

$544=-7.380, p \leq 0.001, r=0.58 ; U=314, z=-4.703, p \leq 0.001, r=0.47)$, respectively.

545

546 4. Discussion

547

548 The principal focus of this study was to estimate visitors' consumer surplus for a MPA in 549 Barbados and to differentiate between visitors use values of natural and artificial reefs. As far as 
550 we are aware, it constitutes the first work to compare use values of two types of reef habitat within

551 a reserve environment.

552

553 It is apparent from our results, that marginal (not significant) differences occurred between visitors

554 WTP for natural reefs (US\$18.33) and estimates for artificial reef use (US\$17.58). Three studies

555 (Johns et al., 2001; Johns, 2004; Oh, Ditton \& Stoll, 2008) have reported use values relating to

556 consumer's surplus of both reef habitats, and all three investigations yielded higher estimates for

557 natural reef usage. Oh, Ditton \& Stoll (2008) estimated an average consumer surplus for diving per

558 trip in Texas waters at US\$171 for natural reef divers and US\$101 for artificial reef divers; a net

559 increase of $70 \%$ per trip for scuba diving at natural reefs. Both Johns et al. (2001) and Johns

560 (2004) estimated consumer's surplus for managing and maintaining the natural and artificial reefs

561 in southeast Florida and Martin County, Florida, respectively. Johns et al. (2001) reported an

562 average use value for residents and visitors at natural reefs of US $\$ 12.74 /$ person-day and

563 US\$8.63/person-day for artificial reefs, at the same location. In a later study, Johns (2004)

564 estimated non-local tourists use value for diving, fishing and snorkelling combined at

565 US\$46.00/person-day at natural reefs, compared to US\$23.84/person-day at artificial reefs.

566

567 It is suggested that a hypothetical bias linked to the 'warm glow' effect (Andreoni, 1990; Christie,

568 2007) may partially account for similar bid values been elicited for both reef types that we

569 investigated. Other environmental studies have identified this phenomenon of impure altruism

570 (Nunes \& Schokkaert, 2003; Polak \& Shashar, 2013), which may be more prevalent among

571 tourists on vacation (Polak \& Shashar, 2013). Indeed, Kahneman \& Knetsch (1992) propose that

572 contingent valuation responses reflect WTP for the moral satisfaction of contributing to public

573 goods - not the economic value of the goods in question, though most (75\%) visitors in this

574 present survey exhibited the motivation of bequest value as the main driver of WTP. In reality,

575 Diamond \& Hausman (1994) believe that WTP would be more conservative if one were asked to

576 pay for it during the surveying process. In spite of this, given at the time the Tiami cruise cost

577 US\$85 per person, it may be plausible that some respondents may have rounded their WTP up to

578 US\$100 regardless of the reef habitat being valued. In fact, $45 \%$ of bid values fell within the

579 US\$10-20 intervals (Table 2).

580 
581 Several variables were significant in influencing WTP. We found that as respondent's age decreased

582 bid value increased, which is not unusual in this type of study. Arin \& Kramer (2002) also noted that 583 younger people were more willing to donate towards reef conservation and Uyarra, Gill \& Côté 584 (2010) found that younger divers had a more positive attitude towards paying higher marine park 585 entrance fees in Bonaire. Moreover, Asafu-Adjaye \& Tapsuwan (2008) reported that Thai 586 respondents accepted the bid in a contingent valuation study more readily as the age of the diver 587 decreased. With regard to older generations, it may be plausible that they are more skeptical about 588 contributing towards conservation efforts in general, or perhaps are more familiar and experienced 589 with the goods being valued, thus reflecting reduced utility and diminishing marginal returns. In 590 fact, we found repeat visitors to the reserve, had a significantly lower bid value than first-time 591 visitors there. This result lends support to Dharmaratne, Sang \& Walling (2000) who noted repeat 592 visitors to a terrestrial park and marine reserve in Barbados and Jamaica respectively, had a lower 593 WTP than first-time visitors. The present study also confirmed that environmental awareness and 594 concern for reefs generally, had a positive effect on payment bids, a trend confirmed in other WTP 595 reef studies (Tapsuwan, 2005; Togridou, Hovardas \& Pantis, 2006; Casey, Brown \& Schuhmann 2010; Hargreaves-Allen, 2010), though not consistent with Barker's (2003) results.

Overall, the number of species viewed had the strongest effect on mean bid value for the marine park fee. The model indicated that each additional species viewed elevated WTP by approximately US\$5.70 (Table 6). This suggests visitors are prepared to pay a significant amount to view wildlife within Folkestone. Indeed, marine life is regarded as one of the greatest sources of revenue for the dive and snorkel tourism industries (Barker, 2003) and viewing it has a positive impact on customer satisfaction (e.g. Musa, 2002; Musa, Kadir \& Lee, 2006; Coghlan, 2012). WTP studies have shown that divers will pay significantly for conservation efforts that favour high biodiversity on artificial coral reefs (Polak \& Shashar, 2013) and for greater fish abundance/size on natural reefs (Rudd \& Tupper, 2002; Barker, 2003; Wielgus et al., 2010). Individuals also hold considerable consumer surplus value for viewing large species such as dolphins, rays, whale sharks and turtles (Davis \& Tisdell, 1999; Schuhmann, Casey \& Oxenford, 2008; Hargreaves-Allen, 2010; Schuhmann et al., 2013; Farr, Stoeckl \& Beg, 2014). In Barbados, turtles provide an additional means to attract tourists to the island (Troëng \& Drews, 2004; Uyarra et al., 2005),

611 being widely promoted in various advertising campaigns. WTP to view turtles is substantial in this 
612 area of the Caribbean. Schuhmann et al. (2013) found divers in Barbados are prepared to pay over

613 US\$57 for the first encounter with a marine turtle, and approximately US\$20 per 2-tank dive for

614 each additional encounter. We also established that turtles are a valuable resource, as they were

615 associated with an US\$8 increase in mean bid value per person, compared to respondents who had

616 not viewed a turtle during their trip.

617

618 Another important aspect of this research was to solicit visitors' opinions on reef material

619 preferences for future purpose-built reef (Supplementary Material). Overwhelmingly, underwater

620 art as sculptures was viewed as the most unappealing material choice. This is despite its reported

621 success in marine parks in Cancun, Mexico and Grenada in the Caribbean

622 (www.underwatersculpture.com). Salient points noted as to visitors general dislike of this type of

623 reef appeared to firmly centre on the lack of available habitat for species refuge, such as holes and

624 crevices for fishes, and also on the 'out of context' appearance of human statues underwater, as

625 well as the small ecological footprint created. On the other hand, Reef Balls ${ }^{\mathrm{TM}}$ (www.reefball.org)

626 presented as a snorkel trail, were viewed more favourably, especially among non-divers.

627 Interestingly, Ramos et al. (2006) concluded that concrete modules were the least important choice

628 of reef material among scuba divers in Portugal. Nevertheless, snorkel trails have been used with

629 notable success in parts of the Caribbean. For example, in Antigua a 5-row Reef Ball ${ }^{\text {TM }}$ breakwater

630 structure (Supplementary Material) also acts as a successful nature trail for snorkellers and divers

631 (Kaufman, 2006), and in the U.S. Virgin Islands, nearly 90\% of the 50,000 annual visitors use a

632 managed snorkel trail (Thorsell \& Wells, 1990). Of significance, Hannak et al. (2011) established

633 that most visitors to a snorkel trail in Dahab, Egypt were willing to pay US\$14-27 for a guided

634 trip. Notwithstanding, purposefully sunken ships were found to be the most popular material

635 choice among 73\% of respondents. In previous studies (Ditton et al., 2002; Stolk, Markwell \&

636 Jenkins, 2005; Shani, Polak \& Shashar, 2011; Kirkbride-Smith, Wheeler \& Johnson, 2013), divers

637 have communicated an immense preference for shipwrecks and deliberately sunken vessels for

638 artificial reef creation Content analysis of our data suggests the appeal of sunken ships is related to

639 their perceived capacity to provide adequate substrate and shelter for marine species, their 'in

640 keeping' generic form and visual appeal, and to their historical fascination.

641

642 4.1 Policy Recommendations 
643

644 Our results demonstrate that almost all (97\%) visitors would be willing to pay a Folkestone Marine

645 Reserve user fee. By combining data of the artificial and natural reef models, our results indicate

646 overseas tourists would be prepared to pay an average of US\$18 as a fee per visit, which could

647 supplement reef conservation finance. This amount is broadly consistent with the results of similar

648 WTP studies (Barker 2003; Mathieu, Langford \& Kenyon, 2003; Tapsuwan, 2005; Hargreaves-

649 Allen, 2010) and is in fact, well above the hypothetical fee structure proposed by the Inter-

650 American Biodiversity Information Network (2010) for the marine reserve in Barbados. In this

651 latter report, a fee of US\$3 to US\$5 for a snorkel tag, and US\$5 to US\$10 for a diving tag, is

652 suggested. Data from this present study could therefore be used to aid the setting of a single, daily,

653 user fee for Folkestone.

654

655 Implementing a successful fee system needs cooperation among visitors, tour operators and 656 managers (Terk \& Knowlton, 2010). To encourage visitors' adoption of fees, they require clarity 657 on how their money is used and managed (Peters \& Hawkins, 2009). Studies suggest that user fee 658 acceptance improves if visitors have knowledge that their funds are managed appropriately (Casey, 659 Brown \& Schuhmann, 2010) and specifically; that money is spent on reef protection (Casey, 660 Brown \& Schuhmann, 2010) and on improving park management (Yeo, 2005). In this study, we 661 found participants concerned over how funds would be used and managed and established that 662 three quarters of visitors wanted a non-governmental organization to manage their payments. To 663 gain support in a fee system, supplying park booklets to visitors detailing the purpose and nature of 664 fees, may assist. In fact, many respondents requested information about the biological aspects of 665 the reserve, as did divers and snorkellers studied by Barker (2003) in St. Lucia. Moreover, by 666 providing meaningful information for tourists, it helps develop place attachment and stewardship 667 (Ham, 1992). Snorkel and dive tour operators also need encouragement to adopt fees. As an 668 incentive to collect them, Terk \& Knowlton (2010) suggest a system for compensating operators 669 administration time, by giving them a small percentage of the fees gathered. This system was 670 originally employed in Mexico (United Nations Environment Programme, 2003) and appears a 671 simple but fair approach.

672 
673 Visitors also need to see 'what they are getting for their money' and good reserve infrastructure

674 helps justify fee payment (Sedley Associates Inc., AXYS Environmental Consulting (Barbados) Inc.

$675 \&$ Scantlebury and Associates Ltd., 2000). This is especially relevant to repeat customers who

676 were noted as having lower WTP (Table $5 \&$ Table 6). Developing eco-tourism opportunities via

677 artificial reefs can create unique selling points in a resort (Dowling \& Nichol, 2001; Leeworthy,

678 Maher \& Stone, 2006; Shani, Polak \& Shashar, 2011; Edney, 2012) and have the potential of

679 drawing visitors to reserves. In previous research (Kirkbride-Smith, Wheeler \& Johnson, 2013) we

680 established that artificial reefs were a prime motivator for some dive tourists to holiday in

681 Barbados. Also, as fish abundance is often greater within protected waters (e.g. Chapman \&

682 Kramer, 1999; Caselle et al., 2015; Sciberras et al., 2015) it appears a fitting environment to

683 deploy artificial reefs for amenity enhancement. Creating a new reef within Folkestone's waters

684 appeared to be very popular among respondents, as over three quarters of those interviewed said

685 this type of resource would encourage repeat visitation. We also discovered that many visitors had

686 heard of artificial reefs and over a third had either snorkelled or dived on one previously, including

687 many deployed in Barbados. Increasingly, artificial reefs are becoming more popular, especially

688 among scuba divers (e.g. Blout, 1981, Scuba Travel, 2006; Edney, 2012; Kirkbride-Smith, Wheeler

$689 \&$ Johnson, 2013), and given the substantial use value we report for them, it suggests visitors

690 would be willing to support a reef substitution policy in Folkestone and potentially in other

691 reserves offering this type of amenity.

692

693 Among the recreationally used natural reefs within the Folkestone Marine Reserve, it is the

694 fringing reefs that are the most impacted (Bell \& Tomascik, 1993; Lewis, 2002; Inter-American

695 Biodiversity Information Network, 2010) and this would appear the most appropriate zone to site

696 underwater attractions. Several benefits could be yielded from developing artificial reefs in

697 reserves. For example, managers may use them to influence and contain visitor use. Creating

698 'honey pot' sites within marine parks has been endorsed by some managers (Clark et al., 2005) as

699 a strategy to conserve other coral reefs by redirecting reef use. Such a policy would be especially

700 useful for managing in-training and novice divers who are documented as causing substantial

701 damage to natural reefs (Roberts \& Harriott, 1994; Walters \& Samways, 2001; Warachananant et

702 al., 2008; Chung, Au\& Qui, 2013). Moreover, these installations could be of value to snorkel and

703 dive companies to help sustain existing local resources. However, concentrating tourist use is open 
704 to debate as Barker (2003) found that visitors disliked the idea of being 'contained', suggesting it 705 would lead to overcrowding and reduced naturalness of an area. In contrast, Hannak et al. (2011)

706 established that a marine viewing trail would be the principal reason that their study group would 707 choose a snorkel or dive site.

708

709

Notwithstanding, artificial reefs have been shown to offer opportunities to view interesting marine

710 life (Wilhelmsson et al., 1998; Perkol-Finkel \& Benayahu, 2004; Arena, Jordan \& Spieler, 2007;

711 Kirkbride-Smith, Wheeler \& Johnson, 2013). Indeed, studies have confirmed that artificial reefs

712 can support a comparable diversity and density of marine species than are found on natural reef

713 outcrops (Clark \& Edwards, 1999; Perkol-Finkel \& Benayahu, 2004), and this is especially true

714 for fish abundance, where in some instances it has exceeded that present on natural reefs (Fast \&

715 Pagan, 1974; Wilhelmsson et al., 1998; Arena, Jordan \& Spieler, 2007; Santos, Oliveira \&

716 Cúrdia, 2013; Granneman \& Steele, 2014). Clearly, creating the right type of artificial reef that

717 encourages a diverse species community is crucial for reef tourism, as this study showed the

718 principal driver of WTP was marine life. In addition, artificial reef development allows for

719 increased accessibility of reefs (Milton, 1989; Stolk, Markwell \& Jenkins, 2005) and arguably,

720 encourages the employment of more robust/resistant environments within reserves (Marion \&

721 Rogers, 1994; Claudet \& Pelletier, 2004). To this end; MPAs provide the greatest opportunity to

722 manage tourism use of natural reefs (Thurstan et al., 2012) and environmental enhancement using

723 'well planned' artificial reef could potentially facilitate this (Oh, Ditton \& Stoll, 2008).

\section{Conclusions and Further Research}

726

727 This study focused on a MPA in Barbados to differentiate between respondents use values of 728 natural and artificial reefs. Our findings show that most visitors are prepared to pay for reef 729 conservation in the Folkestone Marine Reserve, and this represents an unexploited revenue stream 730 that could be used for its day to day management. A mean WTP of US\$18.33 and US\$17.58 was

731 estimated for natural and artificial reef use, respectively. This latter information could aid the 732 setting of a single, daily, user fee for the islands marine reserve. Of importance, our results 733 additionally indicate that significant use value could be gained from the provision of recreation734 orientated artificial reefs within a reserve environment like Folkestone. 
736 This research serves as a valuable foundation for future work that should aim to uncover divers'

737 WTP for 'diving trips' within Barbados's MPA. Also, cruise trip passengers were not represented

738 in this current study, and ideally, this omission needs addressing in future WTP studies for

739 Folkestone. Finally, research into the recovery of non-use values (not current users of the resource)

740 to fund reef management in the Folkestone Marine Reserve, is also an area worthy of future

741 exploration.

742

743

\section{Acknowledgements}

744

745 Our sincere thanks and gratitude extend to Denis Roach, the owner and Chief Executive Officer of 746 Tiami Catamaran Cruises, and to his excellent staff for supporting the data collection period. We

747 thank Jamar Archer, Thomas Atwell, Noddy Banfield, Michael Brown, Michael Captain, Diego De

748 Beauville, Peter Hoad, Ryan Hoyte, Shea Innis, Joshua Roach, Roger Scandella, Sam Sealy and

749 David Young. Additionally, our thanks go to Jeffrey Smith who helped with the data collection

750 and to the reviewers whose helpful comments have greatly improved the final paper. Finally, we

751 thank Will Brown for his permission to use images featured in the supplementary materials

752 section.

753

754

755

756

757

758

759

7. References

760

761 Agace L. 2005. Barbados dive guide: a guide to scuba diving in Barbados. Barbados: Miller

762 Publishing Company, 188.

763

764 Alder J. 1996. Have tropical marine protected areas worked? An initial analysis of their success. 
Andreoni J. 1990. Impure altruism and donations to public goods: a theory of warm-glow giving.

The Economic Journal 100(401):464-477.

769

Arena PT, Jordan LKB, Spieler RE. 2007. Fish assemblages on sunken vessels and natural reefs 771 in southeast Florida, USA. Hydrobiologia 580:157-171.

772

773

Arin T, Kramer RA. 2002. Divers' willingness to pay to visit marine sanctuaries: an exploratory 774 study. Ocean \& Coastal Management 45(2):171-183.

775

776

Arrow K, Solow R, Portney P, Learmer E, Radnar, R, Schuman, H. 1993. Report of the

National Oceanic and Atmospheric Administration Panel on contingent valuation. Washington,

778 DC: Resources for the Future. 66 pp.

779

Asafu-Adjaye J, Tapsuwan S. 2008. A contingent valuation study of scuba diving benefits: case 781 study in Mu Ko Similan Marine National Park, Thailand. Tourism Management 29:1122-1130.

782

Barker NHL. 2003. Ecological and socio-economic impacts of dive and snorkel tourism in St Lucia, West Indies. Ph.D. Dissertation thesis, University of York, UK, 220.

785

Bateman I, Carson RT, Day BH, Hannemann M, Hanleys N, Hett T, Jones-Lee M, Loomes G, Mourato S, Ozdemiroglu E, Pearce D, Sugden R, Swanson J. 2002. Economic valuation with stated preference techniques: A manual. Cheltenham: Edward Elgar Publishing Ltd, 458.

Beggs JA, Horrocks JA, Krueger BH. 2007. Increase in hawksbill sea turtle Eretmochelys imbricata nesting in Barbados, West Indies. Endangered Species Research 3:159-168.

Bell F, Bonn M, Leeworthy V. 1998. Economic impact and importance of artificial reefs in Northwest Florida. NOAA Paper Contract Number MR235. 451 pp. 
796 Bell PRF, Tomascik T. 1993. The demise of the fringing coral reefs of Barbados and of regions in

797 the Great Barrier Reef (GBR) lagoon - impacts of eutrophication. In: Proceedings of the

798 colloquium of global aspect of coral reefs - health, hazards, and history. University of Miami,

799 319-325.

800

801 Blackman K, Goodridge R. 2009. Baseline survey of coral reefs within the Folkestone Marine

802 Reserve, St. James, Barbados. Report no. 5 of the community-based coral reef monitoring and

803 management project. $27 \mathrm{pp}$.

804

805

806

Blaine TW, Lichtkoppler FR, Jones KR, Zondag RH. 2005. An assessment of household

willingness to pay for curbside recycling: a comparison of payment card and referendum

808

809 approaches. Journal of Environmental Management 76:15-22.

Blout S. 1981. Why sports divers like artificial reefs. In: Weaver DB, ed. Artificial reefs:

811

812 Bonham CA, Sacayon E, Tzi E. 2008. Protecting imperiled "paper parks": potential lessons from

813 the Sierra Chinajá, Guatemala. Biodiversity and Conservation 17:1581-1593.

814

815 Boyle KJ. 2003. Contingent valuation in practice. In: Champ A, Boyle KJ, Brown TC, eds. $A$

816 primer on non-market valuation. London: Kluwer Academic Publishers, 111-169.

817

Boyle KJ, MacDonald HF, Cheng H, McCollum DW. 1998. Bid design and yea saying in single-bounded, dichotomous-choice questions. Land Economics 74(1):49-64.

820

Brander LM, van Beukering P, Cesar HSJ. 2007. The recreational value of coral reefs: a metaanalysis. Ecological Economics 63:209-218.

823

824

Brandon K, Redford KH, Sanderson SE. 1998. Parks in peril: people, politics and protected

825 areas. The Nature Conservancy, Island Press, 519.

826 
827 Brock RE. 1994. Beyond fisheries enhancement: artificial reefs and ecotourism. Bulletin of

828 Marine Science 55(2-3):1181-1188.

829

830 Bruner G, Gullison R, Rice R, da Fonseca G. 2001. Effectiveness of parks in protecting tropical 831 biodiversity. Science 291:125-128.

832

833 Bryant D, Burke L, McManus J, Spalding M. 1998. Reefs at risk: a map-based indicator of 834 threats to the world's coral reefs. World Resources Institute, Washington D.C., USA. 56 pp.

835

836 Brylske A, Flumerfelt S. 2004. Assessing the carrying capacity of MPAs: how many visitors can 837 your MPA hold? MPA News 6(2):1-6.

838

839

Burke L, Greenhalgh S, Prager D, Cooper E. 2008. Coastal capital - economic valuation of coral reefs in Tobago and St Lucia. World Resources Institute, Washington D.C., USA. 66 pp.

841

842

Burke L, Maidens J. 2004. Reefs at risk in the Caribbean. World Resources Institute, Washington 843 D.C., USA. 80 pp.

844

Burke L, Reytar K, Spalding M, Perry A. 2011. Reefs at risk revisited. World Resources Institute, Washington D.C., USA. 114 pp.

Burke L, Selig E, Spalding M. 2002. Reefs at risk in Southeast Asia. World Resources Institute, Washington D.C., USA. 72 pp.

850

851 Cameron TA, Huppert DD. 1989. OLS versus ML estimation of non-market resource values 852 with payment card interval data. Journal of Environmental Economics and Management 17:230853246.

855 Caribbean Tourism Organization 2014. Arrivals by main market "Statistics, 2014". Available 856 online at: http://www.onecaribbean.org/statistics/tourismstats (accessed 26 March 2014). 
858 Casey JF, Brown C, Schuhmann P. 2010. Are tourists willing to pay additional fees to protect

859 corals in Mexico? Journal of Sustainable Tourism 18(4):557-573.

860

861 Caselle JE, Rassweiler A, Hamilton SL, Warner RR. 2015. Recovery trajectories of kelp forest 862 animals are rapid yet spatially variable across a network of temperate marine protected areas.

863 Scientific Reports 5: Article number: 14102 DOI 10.1038/srep14102.

864

865 Cesar HSJ. 2000. Coral reefs: their functions, threats and economic value. In: Cesar HSJ, ed.

866 Collected essays on the economics of coral reefs. Kalmar University, Sweden: CORDIO, 14-39.

867

868 Cesar HSJ, Burke L, Pet-Soede L. 2003. The economics of worldwide coral reef degradation.

869 Arnhem, Cesar Environmental Economics Consulting. 23 pp.

870

871 Cesar HSJ, van Beukering PJH. 2004. Economic valuation of the coral reefs of Hawai'i. Pacific

872 Science 58(2):231-242.

873

874 Champ PA. 2003. Collecting survey data for nonmarket valuation. In: Champ PA, Boyle KJ,

875 Brown TC, eds. A primer on nonmarket valuation. London: Kluwer Academic Publishers, 59-98.

876

877 Champ PA, Bishop RC. 2006. Is willingness to pay for a public good sensitive to the elicitation 878 format? Land Economics 82:162-173.

879

880 Chapman MR, Kramer DL. 1999. Gradients in coral reef fish density and size across the 881 Barbados Marine Reserve boundary: effects of reserve protection and habitat characteristics.

882 Marine Ecology Progress Series 181:81-96.

883

884 Chen J, Chuang C, Jan R, Liu L. 2013. Recreational benefits of ecosystem services on and 885 around artificial reefs: a case study in Penghu, Taiwan. Ocean and Coastal Management 886 85(A):58-64. 
888 Christie M. 2007. An examination of the disparity between hypothetical and actual willingness to 889 pay using the contingent valuation method: the case of red kite conservation in the United 890 Kingdom. Canadian Journal of Agricultural Economics 55(2):159-169.

891 Chung S, Au A, Qui J. 2013. Understanding the underwater behaviour of scuba divers in Hong 892 Kong. Environmental Management 51:824-837.

893

894 Clark AM, De Meyer K, Jacobson A, Causey B. 2005. "Sacrificial” areas: an appropriate 895 management tool for MPAs? MPA news 7(3):3-4.

896

897 Clark S, Edwards AJ. 1999. An evaluation of artificial reef structures as tools for marine habitat 898 rehabilitation in the Maldives. Aquatic Conservation: Marine and Freshwater Ecosystems 9:5-21. 899

Claudet J, Pelletier D. 2004. Marine protected areas and artificial reefs: a review of the

901 interactions between management and scientific studies. Aquatic Living Resources 17:129-138.

902

903

Coghlan A. 2012. Facilitating reef tourism management through an innovative importance-

904 performance analysis method. Tourism Management 33(4):767-775.

905

906

Collins KJ, Jensen AC, Albert S. 1995. A review of waste tyre utilization in the marine

907 environment. Chemistry and Ecology 10(3-4):205-216.

908

909

Collins KJ, Jensen AC, Mallinson JJ, Roenelle V, Smith IP. 2002. Environmental impact

910 assessment of a scrap tyre artificial reef. ICES Journal of Marine Science 59:243-249.

911

912 Cooper P, Poe GL, Bateman IJ. 2004. The structure of motivation for contingent values: a case 913 study of lake water quality improvement. Ecological Economics 50(1-2):69-82.

914

915 Crabbe M, McClanahan TR. 2006. A biosocioeconomic evaluation of shipwrecks used for 916 fishery and dive tourism enhancement in Kenya. Western Indian Ocean Journal of Marine Science 917 5(1):35-53.

918 
919 Cumberbatch J. 2001. Case study of the Folkestone Marine Park and reserve, Barbados.

920 Caribbean Natural Resources Institute (CANARI). CANARI technical report no. 281. 11 pp.

921

922 Davis D, Tisdell CA. 1999. Tourist levies and willingness to pay for a whale shark experience.

923 Tourism Economics 5(2):161-174.

924

925 Day JC. 2002. Zoning - lessons from the Great Barrier Reef Marine Park. Ocean and Coastal 926 Management 45:139-156.

927

928 Department of the Environment. 2013. The benefits of marine protected areas. Available at 929 http://www.environment.gov.au/resource/benefits-marine-protected-areas-discussion-paper

930 (accessed 5 August 2013).

931

932 Depondt F, Green E. 2006. Diving user fees and the financial sustainability of marine protected 933 areas: opportunities and impediments. Ocean and Coastal Management 49:188-202.

934

935

De Santo EM. 2013. Missing marine protected area (MPA) targets: how the push for quantity over quality undermines sustainability and social justice. Journal of Environmental Management

937 124:137-146.

938

939

Dharmaratne GS, Brathwaite AE. 1998. Economic valuation of the coastline for tourism in Barbados. Journal of Travel Research 37(2):138-144.

941

942 Dharmaratne GS, Sang FY, Walling LJ. 2000. Tourism potentials for financing protected areas.

943 Annals of Tourism Research 27(3):590-610.

944

945 Diamond PA, Hausman JA. 1994. Contingent valuation: is some number better than no number?

946 Journal of Economic Perspectives 8(4):45-64.

947

948 Ditton RB, Baker TL. 1999. Demographics, attitudes, management preferences, and economic

949 impacts of sport divers using artificial reefs in offshore Texas waters. Technical report no. HD-99- 
950 0. Human Dimensions of Fisheries Lab, Texas A\&M University, College Station, Texas, USA. 44 951 pp.

952

953 Ditton RB, Osburn HR, Baker TL, Thailing CE. 2002. Demographics, attitudes, and reef 954 management preferences of sports divers in offshore Texas waters. ICES Journal of Marine 955 Science 59:186-191.

956

957

Dixon JA, Scura LF, van't Hof T. 1993. Meeting ecological and economic goals - marine parks 958 in the Caribbean. Ambio 22:117-125.

959

960

Dixon JA, Scura LF, van't Hof T. 2000. An economic and ecological analysis of the Bonaire

961 Marine Park. In: Cesar HSJ, ed. Collected essays on the economics of coral reefs, Kalmar

962 University, Sweden: CORDIO, 158-165.

963

964

Doshi A, Pascoe S, Thebau O, Thomas C, Setiasih N, Hong J, True J, Schuttenberg H, Heron 965 S. 2012. Loss of economic value from coral bleaching in S.E. Asia. In: Proceedings of the $12^{\text {th }}$

966 international coral reef symposium. Cairns, QLD, Australia, 9-13 July 2012, 1-5.

967

968

969

Dowling RK, Nichol J. 2001. The HMAS swan artificial dive reef. Annals of Tourism Research

970

971 28(1):226- 229 .

Edney J. 2012. Diver characteristics, motivations, and attitudes: Chuuk Lagoon. Tourism in

973

974

Farr M, Stoeckl N, Beg RA. 2014. The non-consumptive (tourism) 'value' of marine species in

975 the Northern section of the Great Barrier Reef. Marine Policy 43:89-103.

976

977

Fast DE, Pagan FA. 1974. Comparative observations of an artificial tire reef and natural patch

978 reefs off southwestern Puerto Rico. In: Proceedings: artificial reef conference. Texas A\&M

979 University, TAMU-SG-74-103, 49-50.

980 
981 Fitzsimmons C. 2009. Why dive? And why here?: a study of recreational diver enjoyment at a

982 Fijian eco-tourist resort. Tourism in Marine Environments 5(2-3):159-173.

983

984 Google earth. 2016. Available at http://www.google.com/earth (accessed 25 May 2016).

985

986 Granneman JE, Steele MA. 2014. Fish growth, reproduction, and tissue production on artificial

987 reefs relative to natural reefs. ICES Journal of Marine Science 71(9):2494-2504 DOI

988 10.1093/icesjma/fsu082.

989

990 Halpern BS. 2003. The impact of marine reserves: do reserves work and does reserve size matter?

991 Ecological Applications 13(1):117-137.

992

993

Halpern BS, Wallbridge S, Selkoe KA, Kappel CV, Micheli F, D’Agrosa C, Bruno JF, Casey

994 KS, Ebert C, Fox HE, Fujita R, Heinemann D, Lenihan HS, Madin EMP, Perry MT, Selig

995

ER, Spalding M, Steneck R, Watson R. 2008. A global map of human impact on marine

996 ecosystems. Science 319(5865):948-952.

997

998

Halpern BS, Warner RR. 2002. Marine reserves have rapid and lasting effects. Ecology Letters 999 5:361-366.

1000

1001

Ham S. 1992. Environmental interpretation: a practical guide for people with big ideas and small budgets. Golden, CO: Fulcrum/North American Press, 51.

1003

1004

Hannak JS, Kompatscher S, Stachowitsch M, Herler J. 2011. Snorkelling and trampling in

1005 shallow-water fringing reefs: risk assessment and proposed management strategy. Journal of

1006 Environmental Management 92:2723-2733.

1007

1008

Hargreaves-Allen V. 2010. Economic values, distributional impacts and conservation outcomes

1009

for coral reef marine protected areas. Ph.D. Dissertation thesis, Imperial College London, UK, 294.

1010 
1011 Hawkins JP, Roberts CM. 1997. Estimating the carrying capacity of coral reefs for scuba diving.

1012 In: Proceedings of the 8th international coral reef symposium. Smithsonian Tropical Research

1013 Institute, Panama, 24-29 June 1996, 2:1923-1926.

1014

1015 Hime SP. 2008. The effects of marine based tourism on the coral reefs of the British Virgin

1016 Islands. Ph.D. Dissertation thesis, University of East Anglia, UK, 192.

1017

1018 Horrocks JA, Scott NM. 1991. Nest site location and nest success in the hawksbill turtle

1019 Eretmochelys imbricata in Barbados, West Indies. Marine Ecology Progress Series 69:1-8.

1020

1021 Inter-American Biodiversity Information Network. 2010. Barbados reef fix exercise, draft

1022 report: Economic valuation of goods and services derived from coral reefs in the Folkestone Park

1023 and Marine Reserve, Barbados. Draft report prepared by the Inter-American Biodiversity

1024 Information Network. 53 pp.

1025

1026 Johns G. 2004. Socioeconomic study of reefs in Martin County, Florida. Report prepared for

1027 Martin County, Florida by Hazen and Sawyer, P.C., Hollywood, FL. 120 pp.

1028

1029 Johns GM, Leeworthy VR, Bell FW, Bonn MA. 2001. Socioeconomic study of reefs in

1030 Southeast Florida: final report, 2001. Report prepared for Broward County, Palm Beach County,

1031 Miami-Dade County, Monroe County, Florida Fish and Wildlife and Conservation Commission:

1032 Hazen and Sawyer. 348 pp.

1033

1034 Johnson ML, Sandell J. 2014. Advances in marine biology: marine managed areas. London:

1035 Elsevier, 416.

1036

1037 Kahneman D, Knetsch JL. 1992. Valuing public goods: the purchase of moral satisfaction.

1038 Journal of Environmental Economics and Management 22:57-70.

1039 
1040 Kaufman S. 2006. If you build it, they will come? Toward a concrete basis for coral reef

1041 gardening. In: Precht WF, ed. Coral reef restoration handbook. Boca Raton, Florida: CRC Press,

1042 119-142.

1043

1044 Kirkbride-Smith AE, Wheeler PM, Johnson ML. 2013. The relationship between diver

1045 experience levels and perceptions of attractiveness of artificial reefs - examination of a potential

1046 management tool. PLoS ONE 8(7):e.68899 DOI 10.1371/journal.pone.0068899.

Kling CL, Sexton RJ. 1990. Bootstrapping in applied welfare analysis. American Agricultural Economics Association 72:406-418.

Leenhardt P, Low N, Pascal N, Micheli F, Claudet J. 2015. The role of marine protected areas in providing ecosystem services. In: Belgrano A, Woodward G, Jacob U, eds. Aquatic functional biodiversity: An ecological and evolutionary perspective. UK: Elsevier Inc., 211-239.

Leeworthy VR, Maher T, Stone EA. 2006. Can artificial reefs alter user pressure on adjacent natural reefs? Bulletin of Marine Science 78(1):29-37.

S, Warner RR. 2009. Biological effects within no-take marine reserves: a global synthesis. Marine Ecology Progress Series 384:33-46.

1061

Lewis JB. 1960. The coral reefs and coral communities of Barbados, W.I. Canadian Journal of Zoology 38(6): 1130-1145.

Lewis JB. 2002. Evidence from aerial photography of structural loss of coral reefs at Barbados, 1066 West Indies. Coral Reefs 21:49-56.

1067

1068 Lindberg K. 2001. Protected area visitor fees overview. Part of project: generating revenue 1069 through ecotourism for marine protected areas. The International Ecotourism Society and 1070 Programme for Belize. 7 pp. 
1072 Lindsey G, Holmes A. 2002. Tourist support for marine protection in Nha Trang, Viet Nam.

1073 Journal of Environmental Planning and Management 45(4):461-480.

1075 Mahieu P, Riera P, Giergiczny M. 2012. Determinants of willingness-to-pay for water pollution 1076 abatement: a point and interval data payment card application. Journal of Environmental 1077 Management 108:49-53.

Marion JL, Rogers CS. 1994. The applicability of terrestrial visitor impact management strategies to the protection of coral reefs. Ocean and Coastal Management 22:153-163.

Martín-López B, Montes C, Benayas J. 2007. The non-economic motives behind the willingness to pay for biodiversity conservation. Biological Conservation 139:67-82.

Mathieu LF, Langford IH, Kenyon W. 2003. Valuing marine parks in a developing country: a case study of the Seychelles. Environment and Development Economics 8:373-390.

Milton JW. 1989. Artificial marine habitat characteristics and participation behaviour by sport anglers and divers. Bulletin of Marine Science 44(2):853-862.

Mitchell RC, Carson RT. 1989. Using surveys to value public goods: the contingent valuation method. Washington D.C.: Resources for the Future, 463.

Moberg F, Folke C. 1999. Ecological goods and services of coral reef ecosystems. Ecological Economics 29:215-233. 
1100 Mora C, Sale PF. 2011. Ongoing global biodiversity loss and the need to move beyond protected

1101 areas: a review of the technical and practical shortcomings of protected areas on land and sea.

1102 Ecology Progress Series 434:251-266.

1103

1104

Musa G. 2002. Sipadan: a scuba-diving paradise: an analysis of tourism impact, diver satisfaction and tourism management. Tourism Geographies 4:195-209.

1106

Musa G, Kadir SLSA, Lee L. 2006. Layang Layang: an empirical study on scuba divers' satisfaction. Tourism in Marine Environments 2:89-102.

Nunes PALD, Schokkaert E. 2003. Identifying the warm glow effect in contingent valuation. Journal of Environmental Economics and Management 45:231-245.

Oh C, Ditton RB, Stoll JR. 2008. The economic value of scuba-diving use of natural and artificial reef habitats. Society and Natural Resources 21:455-468.

Pendleton LH. 2005. Understanding the potential economic impacts of sinking ships for scuba recreation. Marine Technology Society Journal 39(2):47-52.

Perkol-Finkel S, Benayahu Y. 2004. Community structure of stony corals on vertical unplanned artificial reefs in Eilat, (Red Sea): comparison to natural reefs. Coral Reefs 23:195-205.

Peters H, Hawkins JP. 2009. Access to marine parks: a comparative study in willingness to pay. Ocean and Coastal Management 52:219-228.

Polak O, Shashar N. 2012. Can a small artificial reef reduce diving pressure from a natural coral reef? Lessons learned from Eilat, Red Sea. Ocean and Coastal Management 55:94-100.

1128 Polak O, Shashar N. 2013. Economic value of biological attributes of artificial coral reefs. ICES Journal of Marine Science 70(4):904-912. 
1131 R Development Core Team. 2008. R: a language and environment for statistical computing. $R$

1132 Foundation for Statistical Computing, Vienna, Austria. Available at http://www.R-projects.org.

1133 (accessed 15 August 2014).

1134

1135 Ramos J, Santos MN, Whitmarsh D, Monteiro CC. 2006. The usefulness of the analytic

1136 hierarchy process for understanding reef diving choices: a case study. Bulletin of Marine Science

1137 78(1):213-219.

1138

1139

Rangel MO, Pita CB, Gonçalves JMS, Oliveira F, Erzini K. 2014. Developing self-guided

1140 scuba dive routes in the Algarve (Portugal) and analysing visitors' perceptions. Marine Policy 45:194-203.

1142

Ríos-Jara E, Galván-Villa CM, Rodríguez-Zaragoza FA, López-Uriarte E, Muňoz-

1144 Fernández VT. 2013. The tourism carrying capacity of underwater trails in Isabel Island National Park, Mexico. Environmental Management 52:335-347.

Roberts L, Harriott VJ. 1994. Recreational scuba diving and its potential for environmental impact in a marine reserve. In: Bellwood $\mathrm{O}$, Choat $\mathrm{H}$, Saxena N, eds. Recent advances in marine science and technology. Townsville, Australia, 695-704.

Roman GSJ, Dearden P, Rollins R. 2007. Application of zoning and "limits of acceptable change" to manage snorkelling tourism. Environmental Management 39(6):819-830.

Rudd MA, Tupper H. 2002. The impact of Nassau and grouper size and abundance on scuba dive site selection and MPA economics. Coastal Management 30:133-151.

Santos MN, Oliveira MT, Cúrdia J. 2013. A comparison of the fish assemblages on natural and artificial reefs off Sal Island (Cape Verde). Journal of the Marine Biological Association of the United Kingdom 93(2):437-452. 
1161 Sarkis S, van Beukering PJH, McKenzie E, Brander L, Hess S, Bervoets T, Looijenstijn-van

1162 der Putten L, Roelfsema, M. 2013. Total economic value of Bermuda's coral reefs: a summary.

1163 In: Sheppard C, ed. Coral reefs of the United Kingdom overseas territories: coral reefs of the

1164 world. London: Springer, vol. 1, 201-211.

1165

1166 Schuhmann PW, Casey JF, Horrocks JA, Oxenford HA. 2013. Recreational SCUBA divers'

1167 willingness to pay for marine biodiversity in Barbados. Journal of Environmental Management

1168 121:29-36.

1169

1170 Schuhmann P, Casey J, Oxenford HA. 2008. The value of coral quality to SCUBA divers in

1171 Barbados. In: Proceedings of the $11^{\text {th }}$ international coral reef symposium. Ft. Lauderdale, Florida,

$11727-11$ July 2008. vol. 2, 1149-1152.

1173

1174 Sciberras M, Jenkins SR, Mant R, Kaiser MJ, Hawkins SJ, Pullin AS. 2015. Evaluating the

1175 relative conservation value of fully and partially protected marine areas. Fish and Fisheries 16:58-

117677.

1177

1178 Scuba Travel. 2006. Top 10 dive sites in the world. Available at http//www.scubatravel.co.uk/

1179 topdives.html (accessed 16 July 2014).

1180

1181 Sedley Associates Inc., AXYS Environmental Consulting (Barbados) Inc., Scantlebury and

1182 Associates Ltd. 2000. Feasibility studies of Harrison's Cave and associated site, Carlisle Bay

1183 Marine Park and Folkestone Park and Marine Reserve. Business plan for the proposed Carlisle Bay

1184 marine recreational park and Folkestone marine management area. $101 \mathrm{pp}$.

1185

1186 Seenprachawong U. 2003. Economic valuation of coral reefs at Phi Phi Islands, Thailand.

1187 International Journal of Global Environmental Issues 3(1):104-114.

1188

1189 Selig ER, Bruno JF. 2010. A global analysis of the effectiveness of marine protected areas in

1190 preventing coral loss. PLoS ONE 5(2):e9278 DOI 10.1371/journal.pone.0009278.

1191 
1192 Shani A, Polak O, Shashar N. 2011. Artificial reefs and mass marine ecotourism. Tourism

1193 Geographies 1:1-22.

1194

1195 Skeat A, Skeat H. 2003. Systems to make tourism and others contribute to protected areas in the

1196 Great Barrier Reef. Background paper for the fifth world parks congress, Durban, South Africa.

1197 Available at http://www.conservationfinance.org (accessed 17 December 2013).

Smith JE, Brainard R, Carter A, Grillo S, Edwards C, Harris J, Lewis L, Obura D, Rohwer

F, Sala E, Vroom PS, Sandin S. 2016. Re-evaluating the health of coral reef communities:

1201 baselines and evidence for human impacts across the central Pacific. Proceedings of the Royal

1202 Society B-Biological Sciences 283:20151985; DOI: 10.1098/rspb.

1203

1204 Spash CL. 2000. Assessing the benefits of improving coral reef biodiversity: the contingent

1205 valuation method. In: Cesar HSJ, ed. Collected essays on the economics of coral reefs. Kalmar

1206 University, Sweden: CORDIO, 40-54.

Spash CL. 2006. Non-economic motivation for contingent values: rights and attitudinal beliefs in the willingness to pay for environmental improvements. Land Economics 82:602-622.

Spergel B, Moye M. 2004. Financing marine conservation. A menu of options. Washington D.C.: WWF Centre for Conservation Finance. 68 pp.

STINAPA. 2009. Annual financial report 2008. Kralendijk: Stichting Nationale Parken

1215 Nederlandse Antillean. 28 pp.

Stolk P, Markwell K, Jenkins J. 2005. Perceptions of artificial reefs as scuba diving resources: a study of Australian recreational scuba divers. Annals of Leisure Research 8(2-3):153-173. synopsis and major trends. In: Seaman W, Sprague LM, eds. Artificial habitats for marine and 
1224 Tallman J. 2006. Aesthetic components of ecological restoration. In: Precht WF, ed. Coral reef

1225 restoration handbook. Boca Raton, Florida: CRC Press, 193-203.

1226

1227 Tapsuwan S. 2005. Valuing the willingness to pay for environmental conservation and

1228 management: a case study of scuba diving levies in Moo Koh Similan islands Marine National

1229 Park, Thailand. In: Proceedings of the Australian conference of economists, 1-28.

1230

1231 Terk E, Knowlton N. 2010. The role of SCUBA diver user fees as a source of sustainable funding

1232 for coral reef marine protected areas. Biodiversity 11:78-84.

1233

1234 Therneau T. 2014. A package for survival analysis in S. R package version 2.37-7, Available at

1235 http://CRAN.R-project.org/package=survival (accessed 16 September 2014).

1237 Thorsell J, Wells S. 1990. A global overview of tourism activities in coastal and marine parks. In:

1238 Proceedings of the 1990 congress on coastal and marine tourism. National Coastal Resources

1239 Research and Development Institute, Newport, Oregon, 221-224.

1240

1241 Thur S. 2010. User fees as sustainable financing mechanisms for marine protected areas: an

1242 application to the Bonaire National Marine Park. Marine Policy 34:63-69.

1244 Thurstan RH, Hawkins JP, Neves L, Roberts CM. 2012. Are marine reserves and non-

1245 consumptive activities compatible? A global analysis of marine reserve regulations. Marine Policy

1246 36:1096-1104.

1247

1248 Togridou A, Hovardas T, Pantis JD. 2006. Determinants of visitors' willingness to pay for the 1249 national marine park of Zakynthos, Greece. Ecological Economics 60:308-319.

1251 Troëng S, Drews C. 2004. Money talks: economic aspects of marine turtle use and conservation.

1252 WWF - International, Gland, Switzerland, 41. Available at

1253 http://assets.panda.org/downloads/moneytalks.pdf(accessed 11 June 2014). 
1255 United Nations Environment Programme. 2003. Utility of user fees as financial instruments for

1256 the management of marine parks and marine protected areas in the wider Caribbean region.

1257 Available at http://www.unep.org/documents/utility_of_user_fees.pdf(accessed 10 July 2014).

Uyarra MC, Côté IM, Gill JA, Tinch RRT, Viner D, Watkinson AR. 2005. Island-specific

1260 preferences of tourists for environmental features: implications of climate change for tourism1261 dependent states. Environmental Conservation 32(1):11-19.

1263 Uyarra MC, Gill JA, Côté IM. 2010. Charging for nature: marine park fees and management 1264 from a user perspective. Ambio 39:515-523.

van Treeck P, Schuhmacher H. 1999. Mass diving tourism - a new dimension calls for new management approaches. Marine Pollution Bulletin 37(8-12):499-504.

Varkey D, Ainsworthy CH, Pitcher TJ. 2012. Modelling reef fish population responses to fisheries restrictions in marine protected areas in the coral triangle. Journal of Marine Biology 2012:1-18.

Waite R, Burke L, Gray E, van Beukering P, Brander L, McKenzie E, Pendleton L, Schuhmann P, Tompkins E. 2014. Coastal capital: ecosystem valuation for decision making in the Caribbean. Washington D.C.: World Resources Institute. 78 pp.

Walters RDM, Samways MJ. 2001. Sustainable dive ecotourism on a South African coral reef. Biodiversity and Conservation 10:2167-2179. 
1283 Wells S. 2006. Assessing the effectiveness of marine protected areas as a tool for improving coral

1284 reef management. In: Côté IM, Reynolds JD, eds. Coral reef conservation. UK: Cambridge

1285 University Press, 314-331.

1286

1287 WDPA. 2013. World data base on protected areas. Available at

1288 http://www.wdpa.org/AnnualRelease.aspx (accessed 12 December 2013).

Wielgus J, Balmford A, Lewis TB, Mora C, Gerber LR. 2010. Coral reef quality and recreation fees in marine protected areas. Conservation Letters 3:38-44.

Wilhelmsson D, Ohman MC, Stahl H, Sheslinger Y. 1998. Artificial reefs and dive tourism in Eilat, Israel. Ambio 27(8):764-766.

Yang S, Hu WH, Liu Y. 2012. Consumer willingness to pay for fair trade coffee: a Chinese case study. Journal of Agricultural and Applied Economics 44(1):21-34.

Yeo BH. 2005. The recreational benefits of coral reefs: a case study of Pulau Payar Marine Park, Kedah, Malaysia. In: Ahmed M, Chong CK, Cesar H, eds. Economic valuation and policy

1301 priorities for sustainable management of coral reefs. World Fish Centre Conference Proceedings 1302 70:108-117. 
1304 Table 1. Selected papers and key findings of WTP studies to access coral reefs in MPAs.

1305

1306

1307

1308

1309

Author(s) (year)

Location

Users surveyed

Per

Value per user $^{\mathrm{a}}$

WTP mean

Suggested

Dixon, Scura \&

Bonaire

Divers only

Annum

$\$ 27.40$

1310 van't Hof (2000)

1311 Spash (2000)

$-$

1312 Spash (2000)

Jamaica

Locals \& tourists Annum

$\$ 25.89$

$\$ 2.87 \quad \mathrm{~N} / \mathrm{R}$

1313 Arin \& Kramer (2002)

Curaçao

Locals \& tourists Annum

$\$ 25.21$

$\mathrm{N} / \mathrm{R} \quad \mathrm{N} / \mathrm{R}$

1314 Arin \& Kramer (2002)

Anilao, Philippines

Divers \& snorkellers $\quad$ Visit

$\$ 3.70$

$\$ 3 \quad \$ 4$

Mactan, Philippines

Divers \& snorkellers $\quad$ Visit

$\$ 5.50$

$\$ 5 \quad \$ 5.50$

1315 Arin \& Kramer (2002)

Alona, Philippines

Divers \& snorkellers Visit

$\$ 3.40$

$\$ 3 \$ 4$

1316 Mathieu, Langford \&

Seychelles

Divers \& snorkellers $\quad$ Visit

$\$ 12.20$

$\mathrm{N} / \mathrm{R} \quad \$ 12.20$

1317 Kenyon (2003)

1318 Seenprachawong (2003)

Phi Phi, Thailand

Divers \& snorkellers

$\$ 7.18$

$\mathrm{N} / \mathrm{R} \quad \$ 1$

1319

1320 Notes: ${ }^{a}$ reported in year of study in US dollars. N/R, not recorded in original paper. 
1321 Table 2. Interval selection frequencies of WTP bids (daily, per person).

1322

1323

1324

\begin{tabular}{lclcccc}
\hline Interval (US\$) & \multicolumn{2}{c}{$\begin{array}{c}\text { Raw frequency }(\%) \\
\text { AR data }(\boldsymbol{n}=\mathbf{1 2 5})\end{array}$} & NR data $(\boldsymbol{n}=\mathbf{1 2 5})$ \\
\hline 0 & 7 & $(2.8)$ & 4 & $(3.2)$ & 3 & $(2.4)$ \\
$2-5$ & 4 & $(1.6)$ & 3 & $(2.4)$ & 1 & $(0.8)$ \\
$5-8$ & 22 & $(8.8)$ & 12 & $(9.6)$ & 10 & $(8.0)$ \\
$8-10$ & 26 & $(10.4)$ & 11 & $(8.8)$ & 15 & $(12.0)$ \\
$10-15$ & 70 & $(28.0)$ & 35 & $(28.0)$ & 35 & $(28.0)$ \\
$15-20$ & 43 & $(17.2)$ & 16 & $(12.8)$ & 27 & $(21.6)$ \\
$20-25$ & 42 & $(16.8)$ & 26 & $(20.8)$ & 16 & $(12.8)$ \\
$25-30$ & 12 & $(4.8)$ & 7 & $(5.6)$ & 5 & $(4.0)$ \\
$30-40$ & 11 & $(4.4)$ & 8 & $(6.4)$ & 3 & $(2.4)$ \\
$40-50$ & 6 & $(2.4)$ & 1 & $(0.8)$ & 5 & $(4.0)$ \\
$50-60$ & 4 & $(1.6)$ & 1 & $(0.8)$ & 3 & $(2.4)$ \\
$>60$ & 3 & $(1.2)$ & 1 & $(0.8)$ & 2 & $(1.6)$ \\
\hline
\end{tabular}

1325

1326

1327

1328

1329

1330

1331

1332

1333

1334

1335

1336

Notes: $\mathrm{AR}=$ Artificial reef, $\mathrm{NR}=$ Natural reef. Figures in parenthesis are percentages.

1338

1339

1340

1341

1342

1343

1344

1345

1346

1347

1348

1349

1350

1351

1352

1353

1354

1355

1356

1357 
1358 Table 3. Descriptions of the explanatory variables.

1359

1360

1361

1362

1363

1364

1365

1366

1367

1368

1369

1370

1371

1372

1373

1374

\section{Description}

Continuous: the age of the respondent

Discrete: $1=$ male, $0=$ female

Continuous: number of years the respondent has spent in education

Continuous: number of visits to Barbados

Continuous: level of environmental concern: 1 being the least concerned, 10 being the most concerned

Continuous: how many catamaran cruises undertaken in the Folkestone Marine Reserve?

Discrete: if the respondent had dived in the Folkestone Marine Reserve, $1=$ yes, $0=$ no

Continuous: number of species mentioned in response to open ended question to the no. of species encountered

Discrete: did the snorkel trip satisfy expectations? $1=$ yes, $0=$ no

Discrete: if the respondent rated the fish life viewed as good, $1=$ yes, $0=$ no

Discrete: if the respondent rated the coral life viewed as good, $1=$ yes, $0=$ no

Discrete: if the respondent rated the seawater quality as good, $1=$ yes, $0=$ no 
1375 Table 4. Respondents' WTP to access the Folkestone Marine Reserve (daily, per person) in US\$.

1376

1377

1378

1379

1380

WTP Scenario

Nower ${ }^{\text {a }}$

bound CI

Mean $\pm 1 S D$

Upper

Median

All cata (zero bids in) $250+15.92$

bound CI

138

All data (zero bids in)

$250 \quad 15.92$

$17.45+11.30$

18.96

12.50

All data (zero bids out)

$243 \quad 16.62$

$17.96 \pm 11.05$

19.27

12.50

1382 Artificial reef data

$121 \quad 15.81$

$17.58 \pm 9.96$

19.52

12.50

1383 Natural reef data

122

16.25

$18.33 \pm 12.06$

20.73

15.00

1384

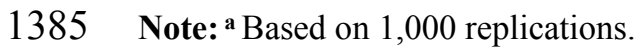

1386

1387

1388

1389

1390

1391

1392

1393

1394

1395

1396

1397

1398

1399

1400

1401

1402

1403

1404

1405

1406

1407

1408 
1411 Table 5. Differences in respondents' mean WTP (US\$) for selected variables.

1412

1413

1414

1415

Variable

Structure

$N$

WTP

$\pm 1 S D$

$P$ value

1416

Gender

Female/Male

$124 / 119$

$19.54 / 16.31 \quad \pm 11.89 / 9.89 \quad p \leq 0.007$

141

Turtle

Yes/No

$196 / 47$

$19.59 / 11.56$

$\pm 11.50 / 5.52 \quad p \leq 0.001$

1418

Dived_FMR

Yes/No

$24 / 52$

$12.50 / 18.55$

$\pm 5.95 / 11.32 \quad p \leq 0.002$

1419

Repeat_trip

Yes/No

$49 / 194$

$13.37 / 18.45$

$\pm 8.12 / 11.74$

$p \leq 0.003$

1420

Activity

Snorkel/Dive

$167 / 76$

$17.89 / 16.45$

$\pm 11.24 / 11.43 \quad p \geq 0.842$

1421

1422

1423

1424

1425

1426

1427

1428

1429

1430

1431

1432

1433

1434

1435

1436

1437

1438

1439 
1440 Table 6. Coefficient estimates of visitors' WTP using ordinary least squares (OLS) and interval (MLE) regression models.

1441

1442

1443

1444

1445

1446

1447

1448

1449

1450

1451

1452

1453

1454

1455

1456

1457

1458

Variable

All data

All data

Artificial reef data

Artificial reef data

Natural reef data

Natural reef

data

Model

OLS

Interval (MLE)

Interval (MLE)

OLS

Interval (MLE)

Intercept

$-6.542 * *$

$-5.958 * *$

$-7.719 * *$

$-7.30 * *$

$-9.401 * *$

$-8.958 * *$

$\bar{A} g e$

$-0.106 * * * \quad-0.103 * * *$

Env_concern

(0.040)

(0.038)

$1.264 * * *$

$1.190 * * *$

(0.331) (0.313)

Dived FMR

$-3.238^{*}$

$-3.149 *$

(1.771)

(1.677)

Coral_life

1459

1460

Species_view

- -

1461

1462

1463

1464

1465

1466

1467

1468

\begin{tabular}{|c|c|c|c|c|c|c|}
\hline & $(0.516)$ & $(0.490)$ & $(0.709)$ & $(0.672)$ & $(0.714)$ & $(0.677)$ \\
\hline$\overline{\text { Model }}$ & $n=243$ & $n=243$ & $n=121$ & $n=121$ & $n=122$ & $n=122$ \\
\hline \multirow[t]{3}{*}{ parameters } & F stat: 71.43 & $\mathrm{Chi}^{2}: 167.99$ & F stat: 37.56 & $\mathrm{Chi}^{2}: 61.6$ & F stat: 43.04 & $\mathrm{Chi}^{2}: 112.21$ \\
\hline & $p<0.001$ & $p<0.001$ & $p<0.001$ & $p<0.001$ & $p<0.001$ & $p<0.001$ \\
\hline & $\mathrm{R}^{2}: 47 \%-$ & & $\mathrm{R}^{2}: 39 \%$ & - & $\mathrm{R}^{2}: 59 \%$ & - \\
\hline
\end{tabular}

$-$

Notes: standard errors in parentheses. Only significant variables shown. ***,**, ${ }^{*}$ Significance at the $p \leq 0.01, p \leq 0.05, p \leq 0.10$ levels, respectively. 


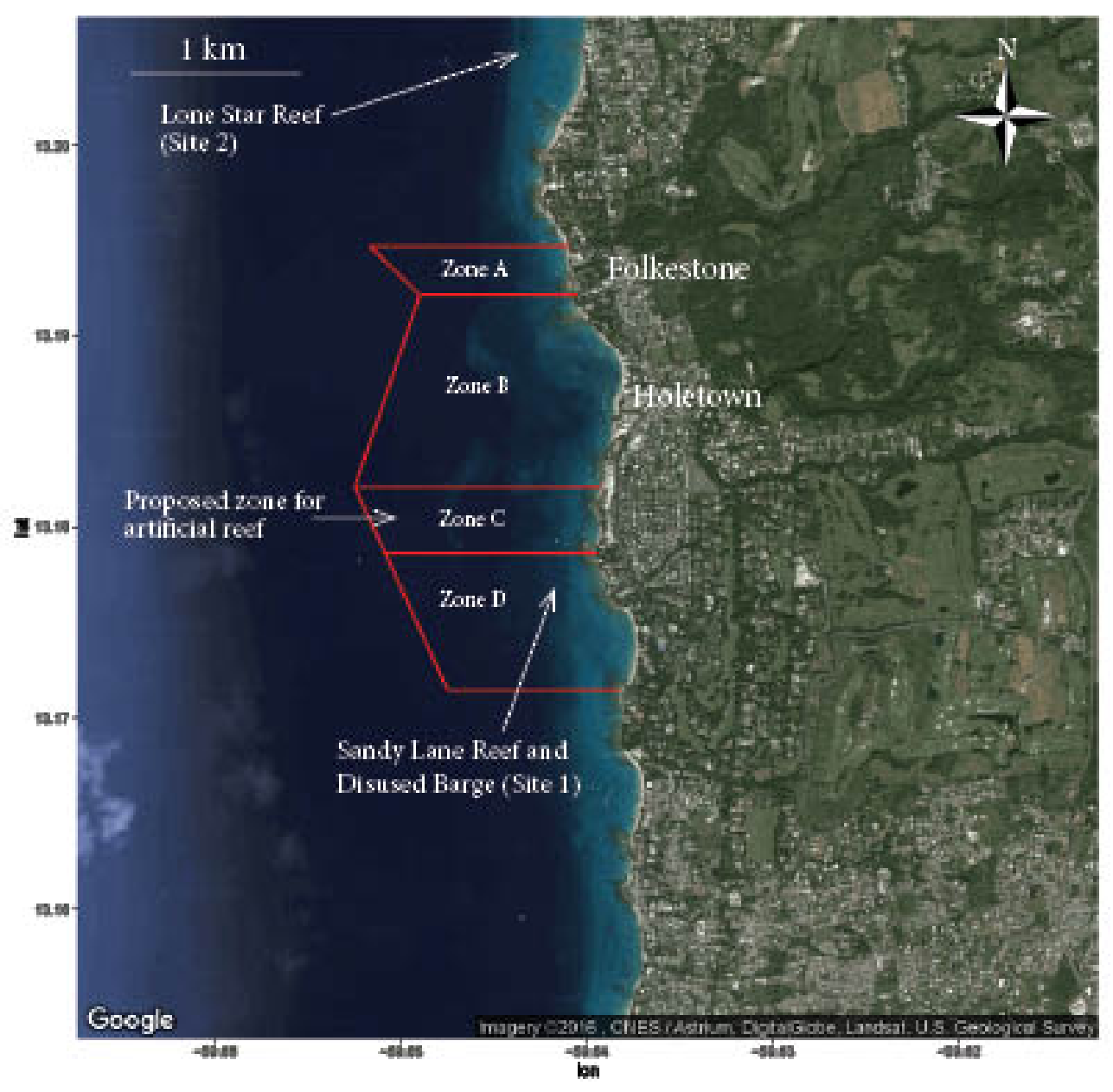

1474 Figure 1. The Folkestone Marine Reserve, Barbados. Map outlining boundary of marine 1475 protected waters and locations of study sites and proposed artificial reef. Zone A: Scientific 1476 Zone $\left(196 \mathrm{~m}^{2}\right)$; Zone B: Northern Water Sports Zone $\left(819 \mathrm{~m}^{2}\right)$; Zone C: Recreational Zone $1477\left(460 \mathrm{~m}^{2}\right)$; Zone D: Southern Water Sports Zone $\left(625 \mathrm{~m}^{2}\right)$ (Modified from: Google earth, 1478 2016). 


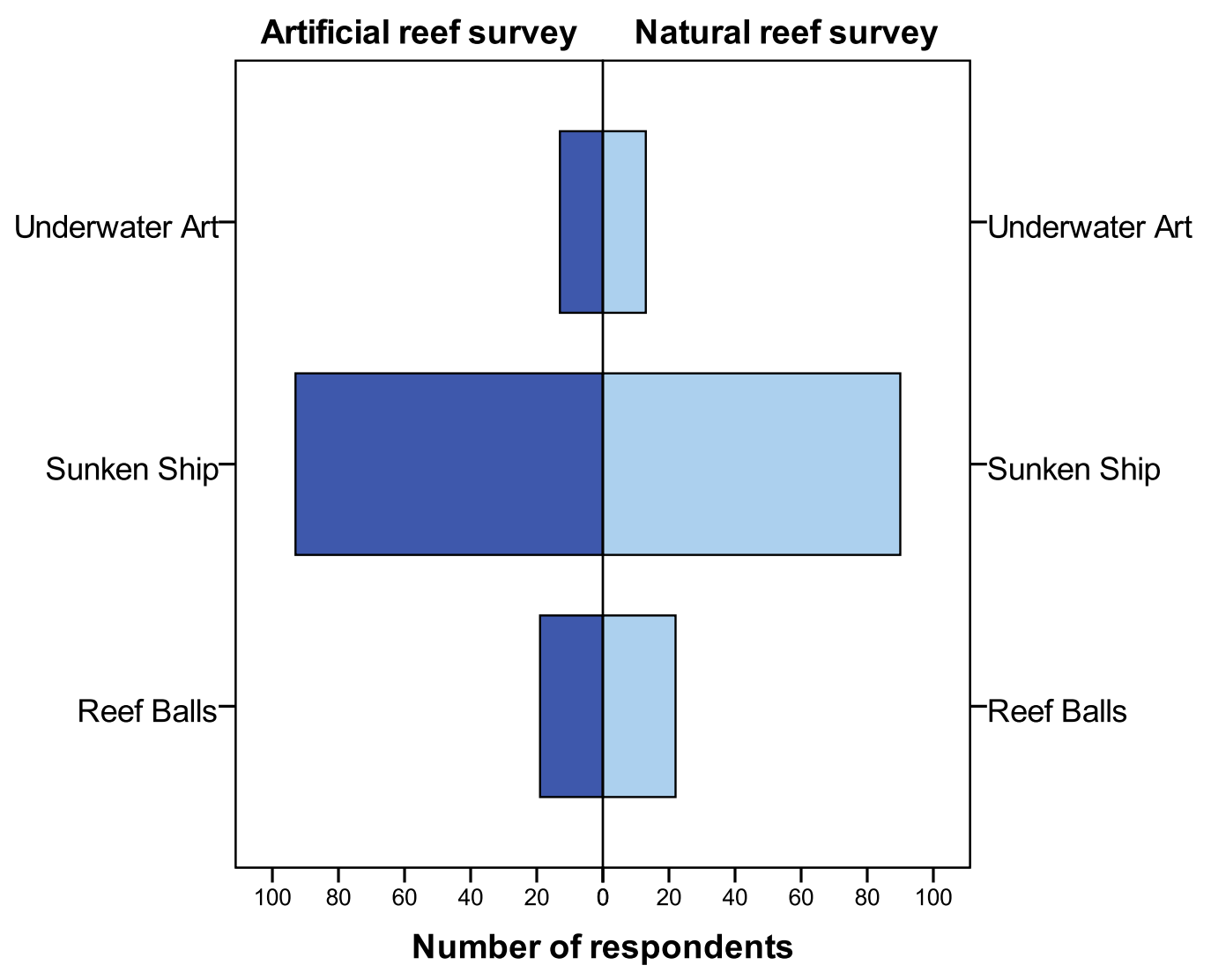

1483

1484 Figure 2. Respondents' preferences for type of artificial reef material for future use in the

1485 Folkestone Marine Reserve. Sample size: $n=243$.

1486

1487

1488 


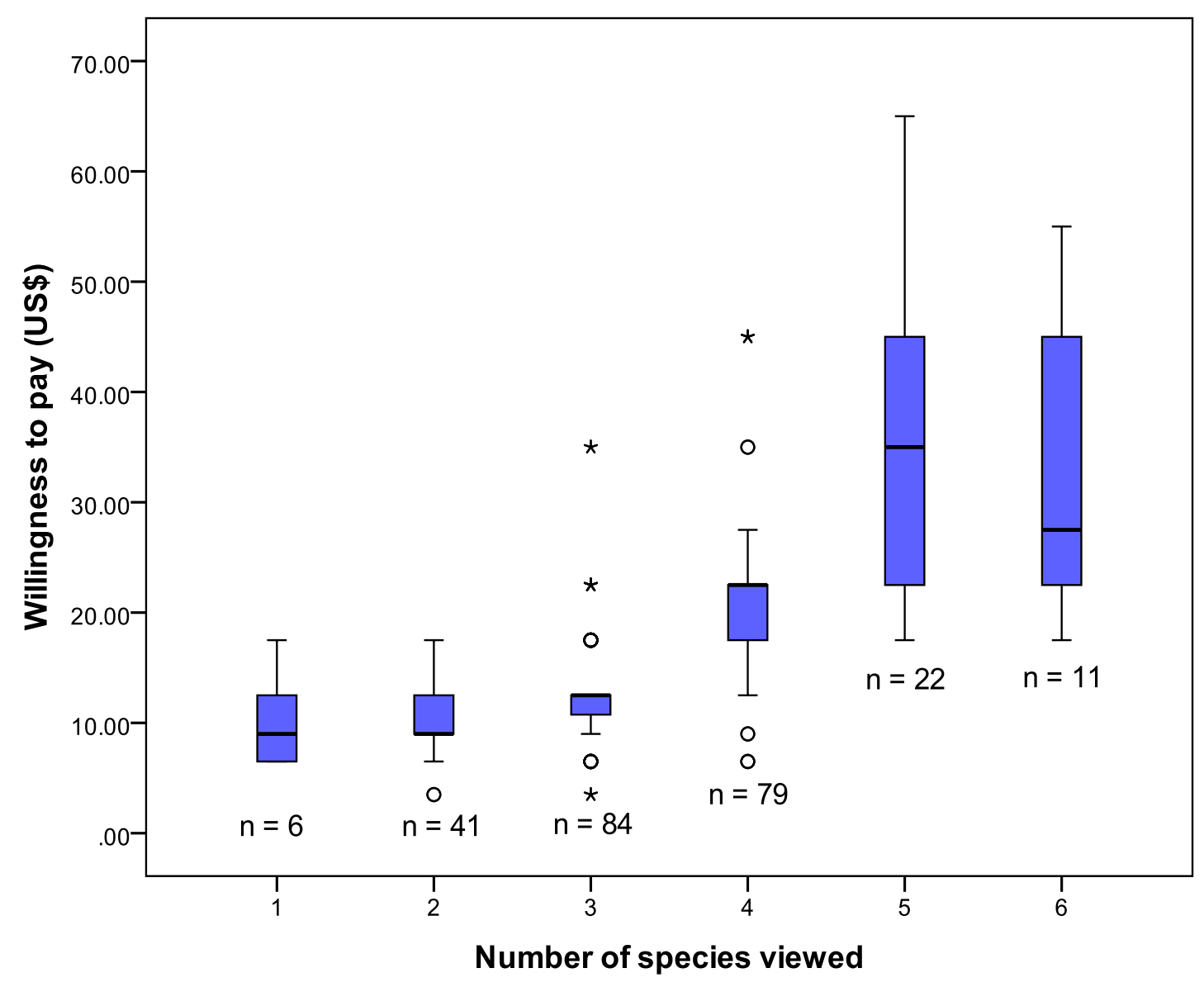

1490 Figure 3. The relationship between the number of marine species viewed and respondents

1491 WTP for reef protection in the Folkestone Marine Reserve (the line is the median, boxes the $149225-75 \%$ quartiles and the whiskers the $95 \% \mathrm{CI}$ ). 